\title{
Holocene Hydroclimate Variability in Central Scandinavia Inferred from Flood Layers in Contourite Drift Deposits in Lake Storsjön
}

\author{
Inga Labuhn ${ }^{1, *}$, Dan Hammarlund ${ }^{1}$ (D), Emmanuel Chapron ${ }^{2}$, Markus Czymzik ${ }^{1,3}$, \\ Jean-Pascal Dumoulin ${ }^{4}$, Andreas Nilsson ${ }^{1}$, Edouard Régnier ${ }^{5}$, Joakim Robygd ${ }^{1}$ \\ and Ulrich von Grafenstein 5 \\ 1 Department of Geology, Lund University, Sölvegatan 12, 22362 Lund, Sweden; \\ dan.hammarlund@geol.lu.se (D.H.); andreas.nilsson@geol.lu.se (A.N.); j.robygd@gmail.com (J.R.) \\ 2 Laboratoire GEODE, UMR 5602 CNRS-Université Toulouse Jean Jaurès, Maison de la Recherche, \\ 5 Allée Antonio Machado, 31058 Toulouse, France; emmanuel.chapron@univ-tlse2.fr \\ 3 Leibniz Institute for Baltic Sea Research (IOW), Marine Geology, 18119 Rostock-Warnemünde, Germany; \\ czymzik@io-warnemuende.de \\ 4 Laboratoire de Mesure du Carbone 14 (LMC14), LSCE/IPSL, CEA-CNRS-UVSQ, Université Paris-Saclay, \\ 91191 Gif-sur-Yvette, France; jean-pascal.dumoulin@lsce.ipsl.fr \\ 5 Laboratoire des Sciences du Climat et de l'Environnement (LSCE/IPSL), UMR 8212 (CEA/CNRS/UVSQ), \\ Université Paris-Saclay, 91191 Gif-sur-Yvette, France; edouard.regnier@lsce.ipsl.fr (E.R.); \\ uli@von-grafenstein.fr (U.v.G.) \\ * Correspondence: inga.labuhn@geol.lu.se; Tel.: +46-46-222-3955
}

Received: 4 December 2017; Accepted: 28 January 2018; Published: 6 February 2018

\begin{abstract}
Despite the societal importance of extreme hydroclimate events, few palaeoenvironmental studies of Scandinavian lake sediments have investigated flood occurrences. Here we present a flood history based on lithological, geochemical and mineral magnetic records of a Holocene sediment sequence collected from contourite drift deposits in Lake Storsjön $\left(63.12^{\circ} \mathrm{N}, 14.37^{\circ} \mathrm{E}\right)$. After the last deglaciation, the lake began to form around $9800 \mathrm{cal} \mathrm{yr} \mathrm{BP,} \mathrm{but} \mathrm{glacial} \mathrm{activity} \mathrm{persisted} \mathrm{in} \mathrm{the}$ catchment for 250 years. Element concentrations and mineral magnetic properties of the sediments indicate relatively stable sedimentation conditions during the Holocene. However, human impact in the form of expanding agriculture is evident from about $1100 \mathrm{cal} \mathrm{yr} \mathrm{BP,} \mathrm{and} \mathrm{intensified} \mathrm{in} \mathrm{the}$ 20th century. Black layers containing iron sulphide appear irregularly throughout the sequence. The increased influx of organic matter during flood events led to decomposition and oxygen consumption, and eventually to anoxic conditions in the interstitial water preserving these layers. Elevated frequencies of black layer occurrence between 3600 and $1800 \mathrm{cal} \mathrm{yr} \mathrm{BP}$ reflect vegetation changes in the catchment as well as large-scale climatic change. Soil erosion during snowmelt flood events increased with a tree line descent since the onset of the neoglacial period ( 4000 cal yr BP). The peak in black layer occurrence coincides with a prominent solar minimum $\sim 2600 \mathrm{cal}$ yr BP, which may have accentuated the observed pattern due to the prevalence of a negative NAO index, a longer snow accumulation period and consequently stronger snowmelt floods.
\end{abstract}

Keywords: lake sediments; palaeo-floods; hydroclimate; deglaciation; black layers; contourite; seismic profile; X-ray fluorescence; environmental magnetism; Holocene; Sweden

\section{Introduction}

Numerous Holocene palaeoclimate studies have been performed in Scandinavia, many of which are based on lake sediment records [1-7]. The Scandes Mountains are particularly important for our understanding of climate variations in this region through their wealth of suitable sites along ecological 
gradients and their proximity to the climatically dynamic North Atlantic region [8-14]. However, previous studies have almost exclusively investigated sediments deposited in small and relatively shallow lakes, predominantly reflecting local-scale environmental dynamics. In contrast, sediment archives from large lakes with more extensive watersheds integrate across regional hydroclimate regimes, although their responses to environmental changes may be subdued due to longer water residence times and relatively insensitive biota $[6,15]$. A number of large and deep lakes are located on the lee side of the Scandes Mountains. Close to 20 of these lakes, which were formed by glacial scouring during repeated glaciations, exceed $100 \mathrm{~km}^{2}$ in areal extent and many are $>100 \mathrm{~m}$ deep. However, sediment records from this type of lake have remained largely unexplored as palaeoclimate archives in Scandinavia, although they have played an important role in the development of highly resolved records of Holocene climate change in continental Europe and other parts of the world [16-19]. In addition, the majority of previously published climate reconstructions from Scandinavia have focused primarily on temperature, while variations in hydroclimate, both gradual changes and extreme events like floods, have been partly overlooked, in spite of their societal importance [20].

Flood occurrences are non-stationary through time and the main driver of their frequency and intensity is the internal and external climate forcing on inter-annual to millennial time-scales [21-25]. However, our knowledge of flood occurrences in Scandinavia is limited due to the general lack of long palaeoclimate records reflecting such extreme events. Reconstructions of past flood occurrences would allow us to better understand their return period as a response to varying climate forcing [26-29] and may improve the anticipation of future flood risks.

During a flood, fine-grained detrital material is eroded in the catchment and transported in suspension into downstream lakes. When the transport capacity of the inflowing tributary stream diminishes in the water body, the terrigenous material is transported through hypo-, meso-, homo- or hyperpycnal flows and is finally deposited as a distinct detrital flood layer on the lake floor [30,31]. Detrital layers have been explored to reconstruct flood occurrences, but such studies are essentially limited to smaller lakes or sites in the vicinity of tributary rivers $[25,26,28,32]$. For larger lakes, currents associated with flood events or linked to specific wind regimes can modify the distribution of flood layers [33-40]. Hyperpycnal flows during flood events are strongly controlled by and tend to maintain, the lake floor morphology (i.e., channels). They can export sediment plumes containing river suspended load far away from the delta into deep basins. Lacustrine contourite deposits have been described in lakes with different basin shapes, depths and circulations patterns, e.g., in Lake Superior [41], East African Lakes [42], Lake Baikal [43], Lake Geneva [35] and Patagonian Lakes [38]. These drift deposits are either resulting from the influence of the Coriolis force on the displacement of sediment plumes at the lake floor, and/or from the interaction of hyperpycnal flood events (or turbidity currents) with currents at the lake floor generated by wind-induced internal waves or gyres.

Here we present a $4 \mathrm{~m}$ thick Holocene sediment sequence from contourite deposits in Lake Storsjön, a large lake on the lee-side of the Scandes Mountains in central Sweden. A particular focus is placed on black layers irregularly intercalated into the background deposition of grey, clay-rich sediments and their potential to serve as a proxy for past changes in the frequency of strong snowmelt floods. In addition, an ensemble of lithological, chemical and mineral magnetic proxies is used to reconstruct variations in catchment dynamics and in-lake processes, providing new insights into the deglaciation history of the site, millennial-scale climatic and environmental changes in the region during the Holocene and human impact on sediment deposition during recent centuries. Based on this multi-proxy approach, we investigate to what extent proxy variability in the sediments of Lake Storsjön relates to large-scale Holocene climate dynamics in Scandinavia. 


\section{Materials and Methods}

\subsection{Study Area}

Lake Storsjön is located in central Sweden $\left(63.12^{\circ} \mathrm{N}, 14.37^{\circ} \mathrm{E}\right.$; Figure 1a). Average annual temperature at the Frösön meteorological station, located on an island in the lake, is $2.5^{\circ} \mathrm{C}$, with average monthly temperatures ranging from $-8.6{ }^{\circ} \mathrm{C}$ in January to $13.4{ }^{\circ} \mathrm{C}$ in July. The average annual precipitation is $491 \mathrm{~mm}$, with $>50 \%$ falling between June and September (Figure 1b; all values refer to the 1960-1990 reference period). The surrounding bedrock is mainly composed of greywackes, shales and limestones of Cambro-Silurian age, partly altered by the Caledonian orogeny, covered by a Quaternary clayey diamicton [44]. The catchment area of about 12,000 $\mathrm{km}^{2}$ extends from the water divide of the Scandes Mountains at a maximum elevation of $1796 \mathrm{~m}$ to the outlet of the lake at $292 \mathrm{~m}$ a.s.l. (Figure 1c). It is dominated by coniferous forest (40\%) and mires, with some cultivated areas on the clay-rich soils on carbonate bedrock. Lake Storsjön itself covers an area of $456 \mathrm{~km}^{2}$, with $13 \%$ of the catchment area consisting of lakes.

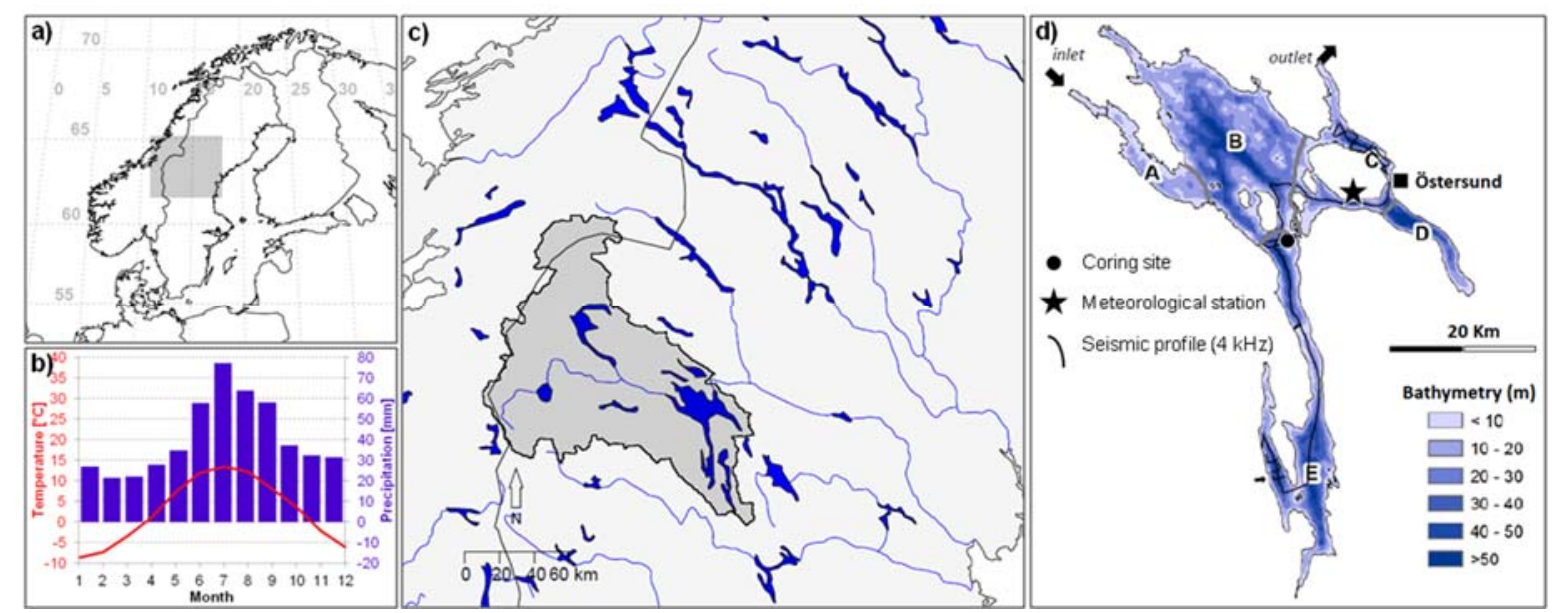

Figure 1. (a) Overview map showing the location of the study area; (b) Climate diagram for the Frösön meteorological station (1961-1990 averages); (c) The catchment of Lake Storsjön (dark grey shading); (d) Bathymetry of Lake Storsjön, position of the coring site (black dot), location of the Frösön meteorological station (black star) and the seismic profiles (black lines). A, B, C, D and E indicate the subdivision of the lake into five principal parts (see text for details).

The lake has a mean depth of $17.3 \mathrm{~m}$, a maximum depth of $74 \mathrm{~m}$ and a volume of $8.02 \mathrm{~km}^{3}$. It can be divided into five principal parts (A to E; Figure 1d) according to its bathymetry and exposure to inlets and to the outlet. Due to the large catchment compared to the size of the lake, its water residence time of about 1 year is relatively short, with a more rapid throughflow in the northern parts of the lake, where the in- and outflows are located and a longer residence time in its southern basins [45].

The average ice cover period of Lake Storsjön lasts from mid-December to mid-May. Snowmelt leads to a distinct peak in river discharge in the catchment in May or June [46]. However, river management at $>10$ hydropower stations upstream of Storsjön's main inlet masks the natural seasonal discharge pattern at the inlet. The lake has been regulated by a dam for hydropower production since 1938, involving yearly water level variations in the range of 290.5-293.3 $\mathrm{m}$ a.s.1. The development of a thermocline at 17-26 m water depth has been recorded in September in several parts (B, C and E) on a number of occasions between 2010 and 2014 [45]. Hydrodynamic simulations revealed significant surface currents associated with prevailing wind patterns during the ice-free season and distinct deeper currents linked to the lake floor morphology [45]. 


\subsection{Seismic Survey}

A seismic survey using a portable $4 \mathrm{kHz}$ chirp digital device (Knudsen; Perth, Canada) and a conventional GPS (Garmin, Olathe, KS, USA) installed on-board a small fishing boat was performed during three days in November 2013 for mapping of the bedrock morphology and sediment geometry, as well as for identification of suitable coring sites. In total, $90 \mathrm{~km}$ of seismic profiles were acquired based on available bathymetric data [45], essentially in parts $C$ and $E$ of the lake, while strong winds and large waves prevented surveying the central basin.

\subsection{Sediment Coring}

Sediment cores were retrieved from the ice-covered lake in April 2014 in a $33 \mathrm{~m}$ deep basin with no major inlets in its vicinity. The seismic data at this location indicated a high sediment thickness and an undisturbed stratigraphy (Figures 2 and 3). An $86 \mathrm{~cm}$ long surface sediment core was obtained using a freeze corer [47]. Seven overlapping $2 \mathrm{~m}$ long sediment cores, $8.3 \mathrm{~cm}$ in diameter, were obtained from three adjacent drill holes using a UWITEC piston corer (Mondsee, Austria).

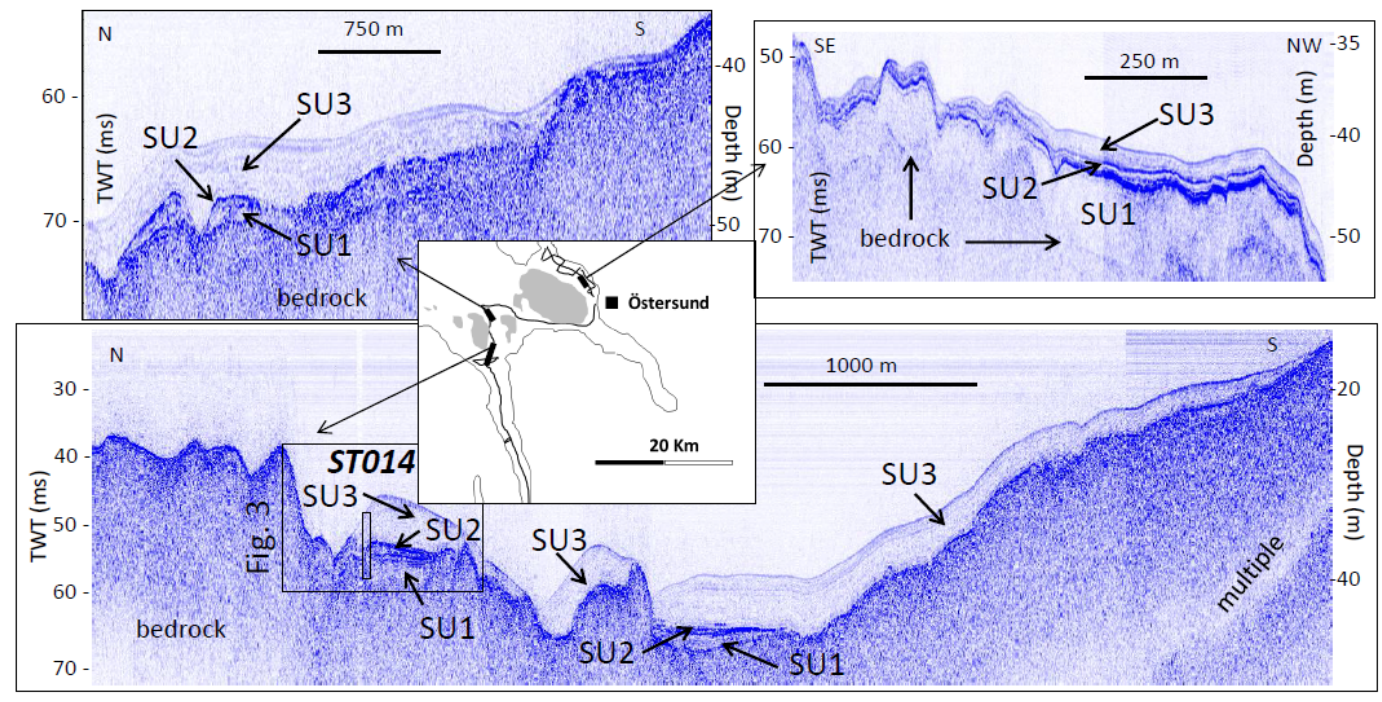

Figure 2. Selected examples of acoustic facies identified on seismic profiles (bold black lines on the map), highlighting the complex morphology of the bedrock and variable successions of seismic units (SU1, SU2 and SU3) across the lake basin. The locations of the coring site (STO14) and Figure 3 are indicated on the bottom panel.

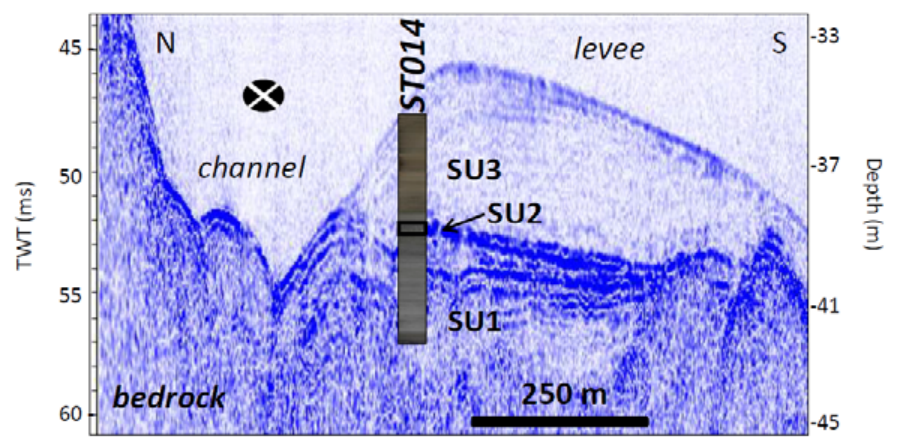

Figure 3. Detail of a seismic profile indicating the correlation of acoustic facies and sedimentary facies from the STO14 sediment sequence as described in supplementary Figure S1. The location of this profile is indicated in Figure 2. 


\subsection{Core Correlation}

A continuous composite sediment profile of $7 \mathrm{~m}$ thickness (STO14) was constructed from the freeze core and the piston cores (supplementary material, Figure S1). The overlapping parts of the piston cores were aligned using 19 macroscopic lithological marker layers. Two of the cores were aligned at $440 \mathrm{~cm}$ based on their coring depths due to absence of clear stratigraphic markers. The freeze core was connected to the uppermost piston core based on six tie points identified in organic matter contents and element concentrations obtained from loss on ignition (LOI) and X-ray fluorescence (XRF) measurements, respectively (see below).

\subsection{Dating and Age Modelling}

Seven terrestrial macroscopic plant remains were identified under a binocular microscope and used for AMS radiocarbon dating at the LMC14 laboratory in Saclay (France) [48-50] and at the Radiocarbon Dating Laboratory at Lund University, Sweden (Table 1). Measured radiocarbon ages were calibrated using the IntCal13 calibration dataset [51] and are expressed as calibrated years before 1950 CE (cal yr BP).

Marker horizons of pollution lead were identified using $\mathrm{Pb}$ concentrations determined by XRF (see below). Enrichment factors of $\mathrm{Pb}$ were calculated relative to a conservative lithogenic element $(\mathrm{Zr})$ and a background value of $\mathrm{Pb}$ according to [52]. A site-specific Pb background was calculated using the part of the sediment sequence deposited prior to $2500 \mathrm{cal} \mathrm{yr} \mathrm{BP,} \mathrm{i.e.,} \mathrm{before} \mathrm{the} \mathrm{earliest} \mathrm{Pb}$ pollution signals [53]. The anthropogenic $\mathrm{Pb}$ contribution was then calculated following [54]. An age uncertainty of \pm 50 years was assigned to the inferred $\mathrm{Pb}$ pollution dates to account for the sampling resolution of 0.5 to $1 \mathrm{~cm}$.

Activities of ${ }^{210} \mathrm{~Pb}$ and ${ }^{137} \mathrm{Cs}$ were measured on the upper $21 \mathrm{~cm}$ of the freeze core with an ORTEC High-Purity Germanium Gamma Detector (AMETEK Inc., Berwin, PA, USA) at the Department of Geology, Lund University. The ${ }^{210} \mathrm{~Pb}$ activity was measured at its gamma peak at $46.5 \mathrm{KeV}$, the ${ }^{224} \mathrm{Ra}$ was determined via its granddaughters ${ }^{114} \mathrm{~Pb}$ at $295 \mathrm{KeV}$ and $352 \mathrm{KeV}$ and ${ }^{114} \mathrm{Bi}$ at $609 \mathrm{KeV}$. Self-absorption corrections were made for ${ }^{210} \mathrm{~Pb}$ on each measurement [55]. The ${ }^{137} \mathrm{Cs}$ activity was measured at the $662 \mathrm{KeV}$ gamma peak.

The age-depth model for the sediment sequence was created with Clam version 2.2 [56] using a smoothing spline with a smooth level of 0.3 , including seven ${ }^{14} \mathrm{C}$ dates, three pollution $\mathrm{Pb}$ dates and one ${ }^{137} \mathrm{Cs}$ date $\left({ }^{210} \mathrm{~Pb}\right.$ dating was not possible due to insufficient sample sizes). The sampling year 2014 ( $-64 \mathrm{cal}$ yr BP) was assigned to the top of the composite profile.

\subsection{Sediment Subsampling}

The sediment sequence was subsampled for lithological, chemical and mineral magnetic analyses. A continuous series of sediment samples was extracted from the freeze core at $1 \mathrm{~cm}$ resolution from 1.5 to $10.5 \mathrm{~cm}$ depth (top sample $0-1.5 \mathrm{~cm}$ ), at $0.5 \mathrm{~cm}$ resolution from 10.5 to $20 \mathrm{~cm}$ depth and at $1 \mathrm{~cm}$ resolution from 20 to $81 \mathrm{~cm}$ depth. The piston cores were sampled using cubic boxes $\left(7 \mathrm{~cm}^{3}\right)$ at $3 \mathrm{~cm}$ resolution, with the topmost sample centred at $1.5 \mathrm{~cm}$ depth. In addition to the regular interval samples, 14 samples were extracted from individual black layers, with a thickness between 0.4 and $0.7 \mathrm{~cm}$.

\subsection{Physical and Chemical Properties}

Grey level values were extracted from a digital greyscale photograph (resolution $300 \mathrm{dpi}$ ) of the sediment sequence, along the vertical axis and averaged over a $2 \mathrm{~cm}$ wide horizontal window. Grey level values are expressed on a scale between 0 (black) and 255 (white).

Grain size distributions were determined for six black layers and six regular sediment (clay gyttja) samples of about $2.5 \mathrm{~g}$ dry weight. Samples were sieved with 250, 125 and $63 \mu \mathrm{m}$ mesh sizes and each fraction was weighed with a precision balance. Three of the black layers and three of the clay 
gyttja samples were inspected at $15 \mathrm{kV}$ with a Hitachi S-3400N (Tokyo, Japan) scanning electron microscope (SEM) at the Department of Geology, Lund University.

$\mathrm{XRF}$ and LOI were measured on the regular interval samples throughout the sequence and on the 14 black layer samples. XRF was measured using a Thermo Scientific Niton XL3t Goldd+ XRF analyser (ThermoFisher Scientific Inc., Waltham, MA, USA) in mining mode $(\mathrm{Cu} / \mathrm{Zn})$ for $180 \mathrm{~s}$. All measurements were duplicated and the presented values are averages of the replicate measurements. Water and organic matter contents were determined by LOI using a Nabertherm muffle furnace (Lilienthal, Germany), following [57]. Samples were first heated to $105^{\circ} \mathrm{C}$ for two hours and then combusted at $550{ }^{\circ} \mathrm{C}$ for four hours. The samples were weighed before and after each step.

\subsection{Mineral Magnetic Properties}

Mineral magnetic measurements were carried out on the regular interval samples at the Lund Paleomagnetic Laboratory. A first set of samples covering the composite sediment sequence was measured in September 2014 and a second set, comprising the overlapping parts of the piston cores, was measured in August 2016. Volume-specific magnetic susceptibilities $(\mathrm{k})$ were measured on all samples using a Geofyzica Brno KLY-2 kappabridge (Brno, Czech Republic). Anhysteretic remanent magnetizations (ARMs) were induced with a peak alternating field (AF) of $80 \mathrm{mT}$ with a direct current (DC) bias field of 50 $\mu \mathrm{T}$ and progressively AF demagnetized at 5, 10, 15, 20, 40, 60 and $80 \mathrm{mT}$. Volume-specific susceptibility of ARM ( $\left.\kappa_{\mathrm{ARM}}\right)$ was calculated by normalizing the ARM intensity by the DC bias field and median destructive field of the ARM (MDF $\left.{ }_{\mathrm{ARM}}\right)$ determined as the AF required to remove $50 \%$ of the induced ARM. ARM measurements were not carried out for samples collected from the freeze core. Saturation isothermal remanent magnetizations (SIRMs) were induced using a Redcliffe model BSM-700 pulse magnetizer (Redcliffe Magtronics Ltd., Bristol, UK) with a DC field of 1T and measured using a Molspin Minispin magnetometer. Backfield IRMs were subsequently induced with a DC field of $100 \mathrm{mT}$ using a Molspin pulse magnetizer and measured using a Molspin Minispin magnetometer (Bartington Instruments Ltd., Witney, UK). S-ratios were determined by dividing the backfield IRM-100mT with the SIRM. After completion of the magnetic measurements, the samples from the composite sequence were freeze dried in order to calculate dry density.

\section{Results}

\subsection{Seismic Survey}

Seismic profiles allowed mapping of the bedrock morphology corresponding to the acoustic substratum (Figures 2 and 3). The complex morphology of the bedrock is typical for lakes of glacial origin, showing numerous over-deepened sub-basins delimited by sills or islands [58]. The bedrock crops out frequently at the lake floor (Figure 2) and is covered by unevenly distributed sediments constituting a succession of seismic units with contrasting acoustic facies. Seismic Unit 1 (SU1) is characterized by a varying thickness across the studied parts of the lake basin, ranging from 0 to 10 milliseconds two-way travel time (ms TWT) and consisting of transparent to chaotic acoustic facies with local high amplitude and continuous reflections (Figure 2). SU1 exhibits maximum thickness in Part C. Seismic Unit 2 (SU2) is characterized by a continuous and high-amplitude reflection and is generally thin $(<1 \mathrm{~ms}$ TWT). In contrast, Seismic Unit 3 (SU3) is characterized by transparent acoustic facies ( $<10 \mathrm{~ms}$ TWT thick) and by the development of several low amplitude continuous reflections parallel to the lake floor that are locally developing onlap terminations on SU2, SU1 or the bedrock (Figures 2 and 3). In addition, SU3 displays a channel-levee configuration typical of (patchy) drift or contourite deposits.

\subsection{Lithological Description}

Three main lithological units (I, II and III) were identified in the sediment sequence (Figure S1). These sedimentary units correspond to the seismic units (SU) identified in 0: Unit I corresponds to SU1, 
Unit II to SU2 and Unit III to SU3 (Figure 3). Unit I (715-399 cm depth) consists of dark grey, poorly sorted, sandy-silty diamictic sediments with abundant gravel and small stones (Subunits Ia, Ib and Id), interrupted by layers of predominantly clayey-silty sediments at two levels (Subunits Ic and Ie). Unit II $(399-354 \mathrm{~cm})$ is sharply distinguished from Unit I and is composed of finely laminated couplets of dark and light grey clay, with thicknesses between 1 and $2 \mathrm{~mm}$. Unit III $(354-0 \mathrm{~cm})$ consists of brownish grey clay gyttja with occasional macroscopic terrestrial plant remains. Throughout Unit III, 335 black layers of 0.1 to $0.7 \mathrm{~cm}$ thickness appear at intervals between 0.2 and $3.5 \mathrm{~cm}$ (Figure 4). After the core opening, their colour changed gradually into reddish-brown. Vivianite concretions around macroscopic plant remains were identified visually (based on the bright blue colour upon exposure to air) within black layers at 153.5, 171, 180.5, 231 and $230 \mathrm{~cm}$ depth. Unit III is subdivided into three parts (Figure 5). Subunit IIIa $(354-190 \mathrm{~cm})$ is of grey colour and shows a steadily increasing organic matter content. Above $190 \mathrm{~cm}$ depth the sediment colour changes gradually from grey to brown, illustrated also by a decrease in grey level value (Figure 5) and the organic matter content remains relatively stable (Subunit IIIlb). Subunit IIIC $(43-0 \mathrm{~cm})$ is defined by the onset of increasing concentrations in several elements (see below). Only Units II and III were analysed in detail for this study, as Unit I does not represent lacustrine sediments and lacks chronological information (see Section 4.1).

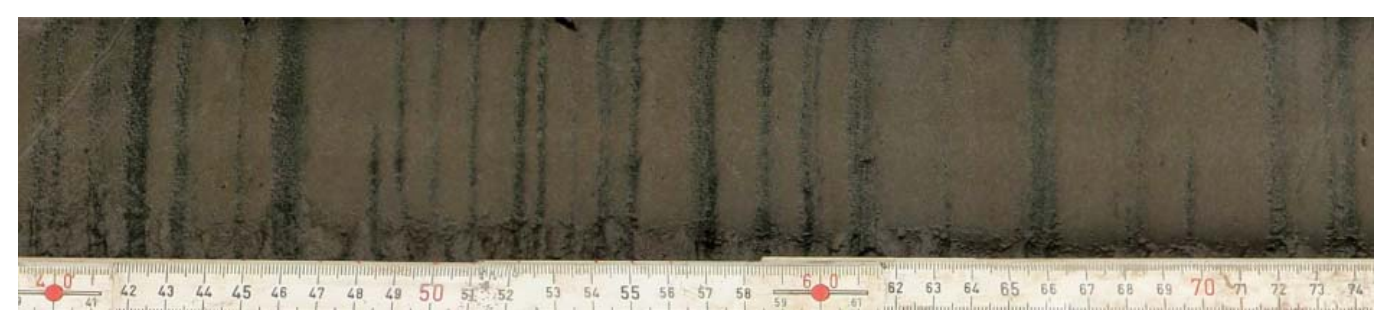

Figure 4. Close-up photograph of the STO14 sediment sequence (Unit III, 28 to $36.5 \mathrm{~cm}$ depth) showing the background sedimentation of brown clay gyttja and the intercalated black layers. The unit on the rule is $\mathrm{cm}$.
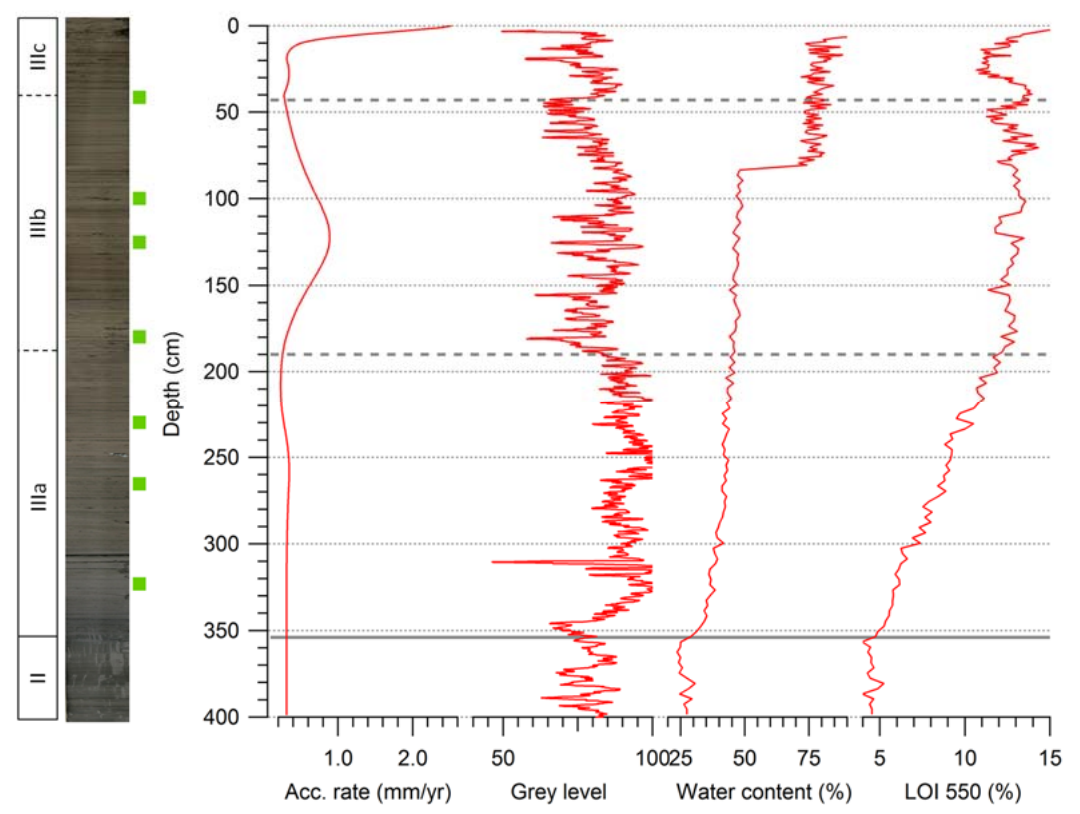

Figure 5. Division of lithological units of the STO14 sediment sequence, composite photograph of the sediments sequence, depths of radiocarbon dates (green squares), accumulation rate, grey level of the photograph, water content and organic matter content (LOI). The abrupt change in water content reflects the different coring techniques (freeze core above $80 \mathrm{~cm}$, piston cores below $80 \mathrm{~cm}$ ), as there is some water loss from the piston cores during storage and sampling. 


\subsection{Age Model and Accumulation Rates}

A distinct ${ }^{137} \mathrm{Cs}$ peak was observed at $5 \mathrm{~cm}$ depth (Figure 6a). Peak activities of ${ }^{137} \mathrm{Cs}$ in lake sediments originate from nuclear bomb tests in the 1960s and the explosion of the Chernobyl nuclear power plant in 1986 CE [59]. Large parts of the Storsjön catchment were affected by ${ }^{137}$ Cs deposition after the Chernobyl accident [60]. It has been shown that ${ }^{137} \mathrm{Cs}$ from the Chernobyl fallout in varved sediment sequences from northern Sweden diffused downward and masked the nuclear bomb test peak [61]. Therefore, the observed ${ }^{137}$ Cs peak in the STO14 sediments likely corresponds to the 1986 $\mathrm{CE}$ fallout and its presence indicates a well-preserved sediment surface.

$\mathrm{Pb}$ concentration peaks in lake sediments can be linked to well-dated events of anthropogenic $\mathrm{Pb}$ emissions and widespread, airborne pollution, e.g., at ca. 750 and $420 \mathrm{cal} \mathrm{yr} \mathrm{BP}$ due to intensified metallurgy in Europe and around $-25 \mathrm{cal} \mathrm{yr}$ BP due to the use and subsequent ban of leaded petrol $[62,63]$. The $-25 \mathrm{cal}$ $\mathrm{yr}$ BP peak can be clearly identified in the STO14 sequence. Two other $\mathrm{Pb}$ peaks are interpreted to reflect the 750 and 420 cal yr BP increases in anthropogenic $\mathrm{Pb}$, which have also been identified in other Swedish lakes $[53,64]$ (Figure $6 \mathrm{~b}$ ). Although these $\mathrm{Pb}$ peaks are not very distinct in the STO14 sediment sequence, the inferred dates are in good agreement with adjacent ${ }^{14} \mathrm{C}$ and ${ }^{137} \mathrm{Cs}$ dates.

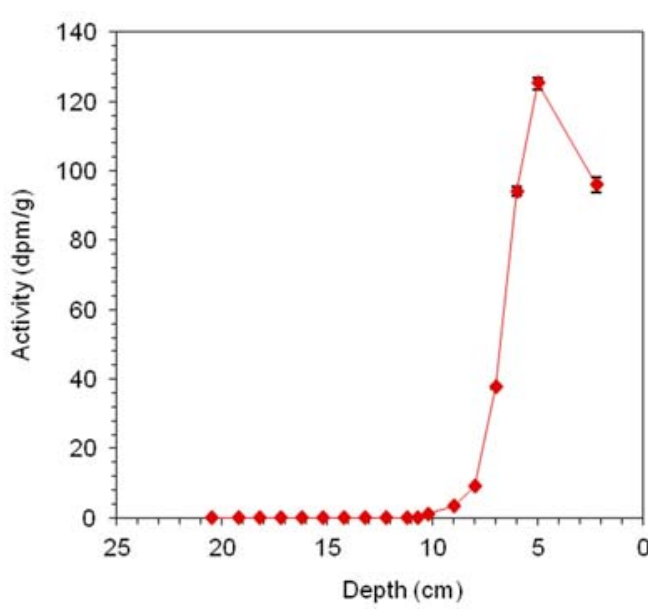

(a)

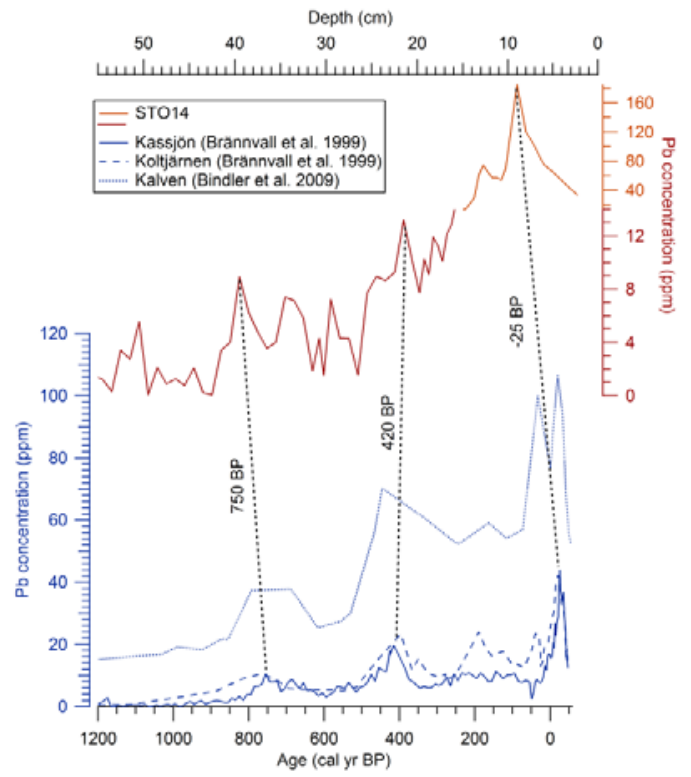

(b)

Figure 6. Chronological markers in the STO14 sediment sequence. (a) ${ }^{137}$ Cs activity for the upper $20 \mathrm{~cm}$. (b) Calculated anthropogenic Pb concentration (red/orange line) and reference curves from varve-dated Swedish lakes (blue lines): Kalven (total Pb) [64]; Kostjärn and Kassjön (anthropogenic $\mathrm{Pb}$ ) [53]. See text for details on the calculation of the anthropogenic $\mathrm{Pb}$ concentration. Note that the $\mathrm{STO} 14 \mathrm{~Pb}$ concentration data are plotted on different scales to account for different orders of magnitude. The dashed lines indicate the tie points used to infer the pollution $\mathrm{Pb}$ dates included in the age model.

The radiocarbon dates are presented in Table 1. The age model indicates no age reversals or apparent hiatuses (Figure 7). As no plant macrofossils for radiocarbon dating were found below $320 \mathrm{~cm}$ depth, the age model was extrapolated below this point. Sediment facies like the finely laminated sediments found in Unit II are commonly interpreted as glaciolacustrine varves in Scandinavian lakes, with couplets of light and dark layers defined as one annual sedimentation cycle reflecting the seasonally varying glaciofluvial discharge in ice-proximal settings $[65,66]$ (see also Section 4.1). Repeated counts of the dark-light couplets in Unit II yielded $250( \pm 5)$ varves and a mean annual sedimentation of $1.8 \mathrm{~mm}$. Since the radiocarbon-based age model placed the boundary between Units 
II and III at $9550 \pm 200 \mathrm{cal}$ yr BP, the lower boundary of Unit II is tentatively assigned an age of $9800 \pm 205 \mathrm{cal} \mathrm{yr}$ BP based on counting of the assumed varves.

Sediment accumulation rates are relatively constant from 9550 to $3500 \mathrm{cal}$ yr BP (on average $0.3 \mathrm{~mm} /$ year), with elevated values between 3500 and $1500 \mathrm{cal} \mathrm{yr} \mathrm{BP} \mathrm{(maximum} 0.89 \mathrm{~mm} /$ year around $2600 \mathrm{cal}$ yr BP). The highest accumulation rates ( $>2 \mathrm{~mm} /$ year) are found in the upper $2 \mathrm{~cm}$ of the sediment sequence.

Table 1. Radiocarbon dates from the STO14 sediment sequence. Samples were measured at the Laboratoire de Mesure du Carbone 14 (LMC 14), Université Paris-Saclay, France (Sac) and at the Radiocarbon Dating Laboratory, Lund University, Sweden (Lu).

\begin{tabular}{ccccc}
\hline Depth $(\mathbf{c m})$ & Material & ${ }^{\mathbf{1 4}} \mathbf{C}$ Age BP \pm Error & Cal. Age BP (2 $\boldsymbol{\sigma}$ Range) & Lab. ID \\
\hline 41.6 & Wood fragment & $1165 \pm 30$ & $985-1177$ & SacA39831 \\
100.4 & Twig & $2330 \pm 30$ & $2213-2431$ & SacA39833 \\
124.5 & Wood fragment & $2540 \pm 30$ & $2497-2747$ & SacA39832 \\
180.2 & Twig & $3410 \pm 30$ & $3577-3811$ & SacA39834 \\
229.8 & Wood fragments & $4950 \pm 35$ & $5603-5740$ & SacA39836 \\
264.4 & Twig & $5915 \pm 40$ & $6657-6847$ & SacA39835 \\
322.9 & Wood fragment & $7785 \pm 45$ & $8447-8639$ & LuS11056 \\
\hline
\end{tabular}

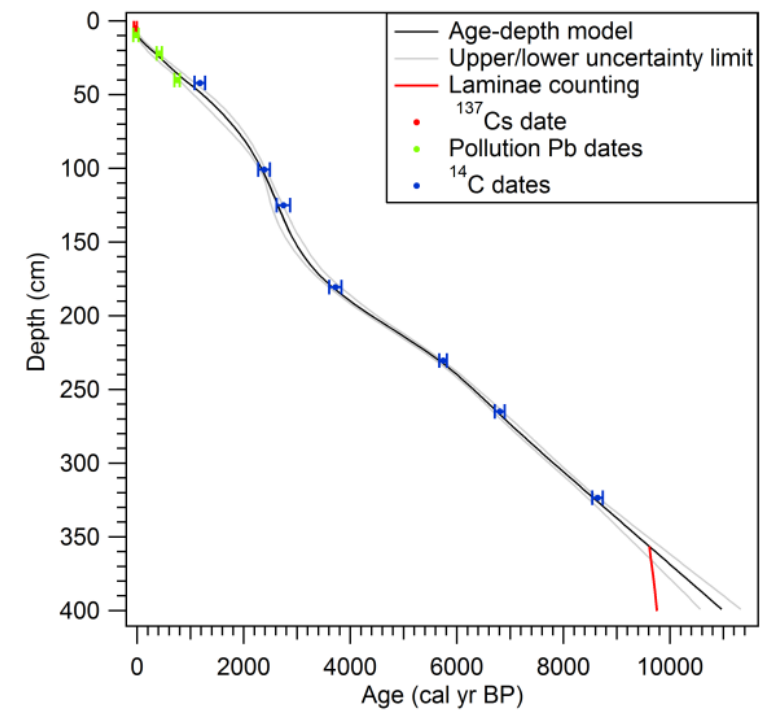

Figure 7. Age-depth model for the STO14 sediment sequence based on radiocarbon dates (blue dots), pollution $\mathrm{Pb}$ marker horizons (green dots) and the ${ }^{137} \mathrm{Cs}$ activity peak (red dot). The year 2014 was assigned to the top of the sequence. The model was calculated with Clam version 2.2 [56] using a smooth spline with a smoothing level of 0.3. The red line illustrates the layer counting in Unit II (354-399 cm), assuming annual layers. The topmost lamina was assigned an age corresponding to the extrapolated ${ }^{14} \mathrm{C}$ age at this depth.

\subsection{Chemical Sediment Properties}

Organic matter contents are relatively stable around 4.5\% throughout Unit II (Figure 5). From the Unit II-III boundary the organic matter content increases steadily throughout Subunit IIIa to about $12.5 \%$ around $4000 \mathrm{cal}$ yr BP. In Subunits IIIb and IIIc organic contents become more variable, fluctuating between $10 \%$ and $14 \%$ but there is no long-term trend in these Subunits. The highest organic matter content of $15 \%$ is found in the topmost sample (Figure 5).

Concentrations of $\mathrm{Ti}$ (Figure 8) and other lithogenic elements ( $\mathrm{Zr}, \mathrm{Rb}, \mathrm{K}$ and $\mathrm{Al}$; not shown) display largely similar patterns throughout the sediment sequence, with high values in Unit II (prior to $9500 \mathrm{cal}$ yr BP), a constant decrease throughout Unit IIIa (to about $4000 \mathrm{cal}$ yr BP), low values in Unit IIIlb 
(between 4000 and $1100 \mathrm{cal} \mathrm{yr} \mathrm{BP)} \mathrm{and} \mathrm{an} \mathrm{increase} \mathrm{throughout} \mathrm{Unit} \mathrm{IIIc} \mathrm{(from} \mathrm{ca.} 1100 \mathrm{cal} \mathrm{yr} \mathrm{BP} \mathrm{to}$ present). The average correlation between the lithogenic elements is $0.90(p<0.001)$ and they are all negatively correlated with organic matter contents $(r=-0.82 ; p<0.001)$. Si concentrations are not strongly correlated with the lithogenic elements $(r=-25 ; p<0.05)$, indicating that rather than clastic input, Si reflects diatom productivity [67]. Ca concentrations are highly variable in Unit II and reach up to $12,000 \mathrm{ppm}$. There is relatively little variation in Unit IIIla, with concentrations around $6100 \mathrm{ppm}$. In Unit IIIb concentrations are even lower (5500 ppm on average) until they increase again throughout Unit IIIc (Figure 8). Ca concentrations are negatively correlated with organic matter content $(r=-0.40)$ and positively correlated with the lithogenic elements (mean $r=0.51$ ). The transition from Unit II to III is also characterized by elevated $\mathrm{Zr} / \mathrm{K}$ ratios (Figure 8), pointing to a coarser grain size [68], as well as by an increase in the water content of the sediments (Figure 5). Mo/ Al ratios are low throughout Unit II, indicating oxic conditions at the sediment-water interface [69,70], then increase abruptly at the Unit II-III transition, followed by several minor peaks. From ca. $8000 \mathrm{cal} \mathrm{yr} \mathrm{BP} \mathrm{onward,} \mathrm{Mo/Al} \mathrm{ratios} \mathrm{increase}$ slowly and steadily until another peak is reached at the top of the sediment sequence. $S$ concentrations show similar patterns and are significantly correlated with $\mathrm{Mo} / \mathrm{Al}$ ratios $(r=0.59 ; p<0.001)$.

Overall, synchronous changes or breakpoints can be observed in several element concentrations and ratios at the Unit II-III boundary (ca. $9500 \mathrm{cal} \mathrm{yr} \mathrm{BP),} \mathrm{at} \mathrm{the} \mathrm{Subunit} \mathrm{IIIa-IIIb} \mathrm{boundary} \mathrm{(ca.} 4000 \mathrm{cal}$ yr BP) and at the Subunit IIIlb-IIIc boundary (ca. 1100 cal yr BP). Concentrations of several elements, including $\mathrm{Pb}$ (Figure 6), $\mathrm{Cu}, \mathrm{S}$ and $\mathrm{P}$ (Figure 8), increase rapidly in the topmost sediment samples.

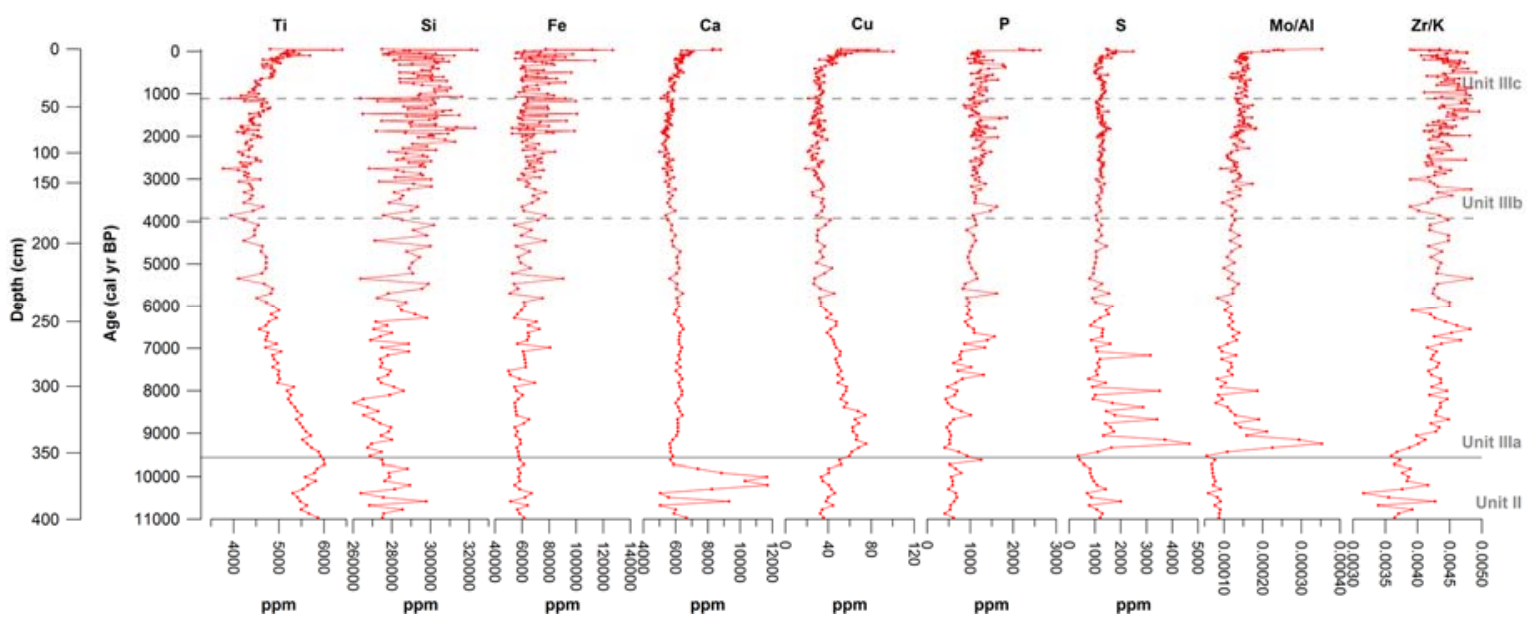

Figure 8. X-ray fluorescence (XRF) profiles for selected elements (in ppm) and element ratios of the STO14 sediment sequence. The solid and dashed grey lines indicate the boundaries between lithological units and subunits, respectively.

\subsection{Mineral Magnetic Properties}

Variations in dry densities and $\mathrm{k}$ are more or less synchronous, showing high values at the bottom (Unit II), which gradually decrease towards the top (Unit III) (Figure 9). This is broadly interpreted as a decrease in the minerogenic content of the sediments, in agreement with Ti concentrations (Figure 8) and the opposite trend in LOI (Figure 5). Magnetic parameters sensitive to the ferrimagnetic content ( $\kappa_{\mathrm{ARM}}$ and SIRM) do not follow the same trend, which suggests changes in the mineral magnetic assemblage, e.g., due to the introduction of a new detrital or biogenic magnetic component. S-ratios, which provide a measure of the relative amounts of high ("hard") vs. low ("soft") coercivity of remanence magnetic minerals, show only subtle variations throughout the sediment sequence. In general, values approaching -1 correspond to a softer magnetic assemblage, typical of (titano)magnetites, while higher values suggest that part of the signal is carried by magnetically harder (antiferrimagnetic) minerals such as haematite or goethite. 
Three samples near the base of Unit IIIa show unusually high SIRM values (and high S-ratios), which may at least partially be explained by measurement errors. These measurements, conducted on the first set of samples which have since been used for other analyses, were not reproduced in any of the second set samples from overlapping cores. Relatively high SIRM/ $\mathrm{K}$ ratios $\left(15-35 \mathrm{kAm}^{-1}\right)$ of these three samples could suggest the presence of authigenic greigite [71]. Greigite, which is a ferrimagnetic iron sulphide, dissolves when exposed to oxygen, which could explain the failure to reproduce these measurements in the second sample set. Peaks in sulphide concentrations (Figure 8) coinciding with the depths of these samples provide further support for the presence of greigite.

The ratio of $K_{A R M}$ to SIRM, often used as a grain-size indicator [72,73], varies between ca. 0.4 and $0.8 \mathrm{~mm} / \mathrm{A}$. The lowest values, corresponding to coarser magnetic grain sizes, are observed in Unit II while Unit III is characterized by generally smaller magnetic grain sizes. $\mathrm{MDF}_{\mathrm{ARM}}$, which is a coercivity sensitive parameter, shows a sharp increase at the boundary between Unit II and Unit III and then gradually increases up to $45 \mathrm{mT}$ in Unit IIIlb, indicative of the presence of bacterial magnetite [74]. Overall the $\kappa_{\mathrm{ARM}} / \mathrm{SIRM}$ and $\mathrm{MDF}_{\mathrm{ARM}}$ values are consistent with a simple system consisting of a mixture two end-members as defined by [74]: (i) a detrital component ( $\kappa_{\mathrm{ARM}} / \mathrm{SIRM} \approx 0.5 \mathrm{~mm} / \mathrm{A}, \mathrm{MDF}_{\mathrm{ARM}}$ $\approx 30 \mathrm{mT}$ ), which is essentially Unit II; and (ii) a soft biogenic component ( $\mathrm{K}_{\mathrm{ARM}} / \mathrm{SIRM}>0.8 \mathrm{~mm} / \mathrm{A}$, $\mathrm{MDF}_{\mathrm{ARM}} \approx 45 \mathrm{mT}$ ) that becomes gradually more important in Unit IIIa and Unit IIIlb. In Unit IIIc there is

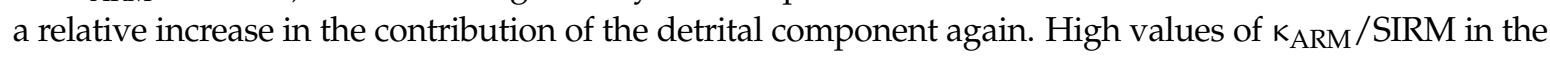
lower part of Unit IIIa are not satisfactorily explained by this simple model and could potentially indicate the presence of a third magnetic component (e.g., greigite, see above).
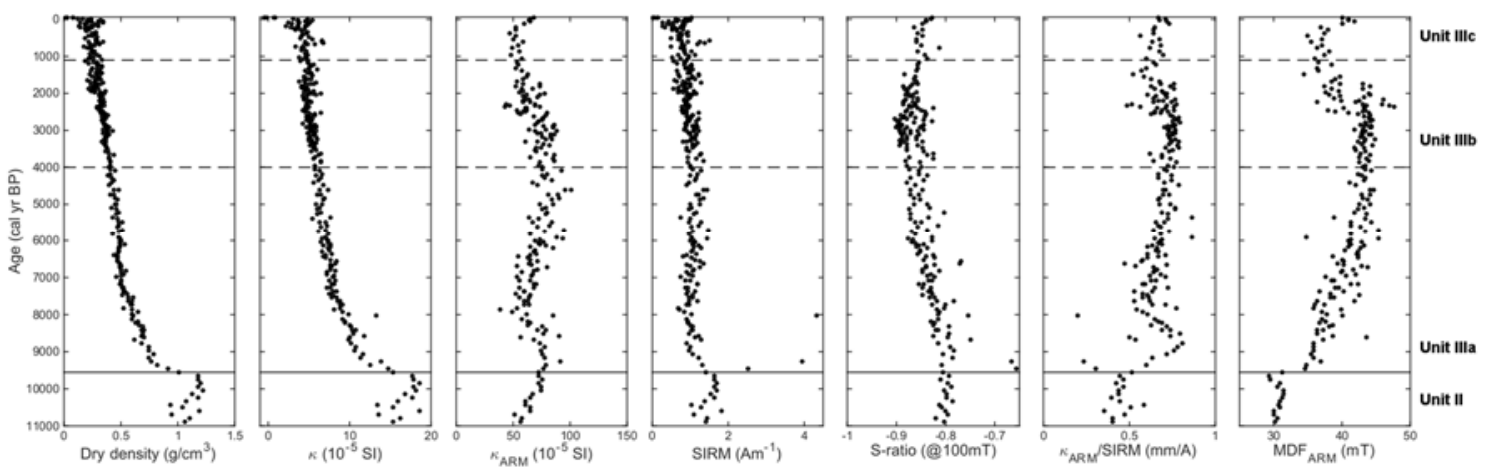

Figure 9. Mineral magnetic parameters of the STO14 sediment sequence. From left to right: dry density, volume-specific magnetic susceptibility ( $($ ), volume-specific susceptibility of anhysteretic remanent magnetizations (ARM, $\mathrm{K}_{\mathrm{ARM}}$ ), saturation isothermal remanent magnetization (SIRM), S-ratio $\left(\mathrm{IRM}_{-100 \mathrm{mT}} / \mathrm{SIRM}\right), \mathrm{K}_{\mathrm{ARM}} / \mathrm{SIRM}$ ratio and median destructive field of ARM (MDF $\left.\mathrm{ARM}\right)$. The solid and dashed grey lines indicate the boundaries between lithological units and subunits, respectively.

$\mathrm{K}_{\mathrm{ARM}} / \mathrm{SIRM}$ ratios around 2-3 mm/A have been shown to be diagnostic of magnetosome chains produced by cultured magnetotactic bacteria [75], although lower values have also been reported for occurrences in natural sediments [76]. It has been found that $\mathrm{K}_{\mathrm{ARM}} / \mathrm{SIRM}$ ratios of biogenic magnetite are particularly low under anoxic conditions [74], which may explain the generally modest values recorded here.

\subsection{Characterization and Temporal Distribution of Black Layers}

The three black layer samples and the three background gyttja samples examined by SEM each showed similar characteristics. Black layers are composed of dominantly minerogenic particles and aggregates, whereas the clay gyttja contains more autochthonous biogenic material, e.g., diatoms (Figure 10). The Storsjön sediments are generally fine-grained with ca. 95 weight \% belonging to the silt and clay fractions. The black layers are characterized by a slightly larger grain size than the clay 
gyttja (Figure 11). The grain size proxy $\mathrm{Zr} / \mathrm{K}$ [68] also indicates a larger average grain size of the black layers compared to bulk sediment samples (Figure 11).

The content of organic matter is slightly higher in the black layers (14\%) than in the bulk sediment samples (12\%) (Figure 11). Ti (Figure 11) and other lithogenic elements ( $\mathrm{Zr}, \mathrm{Rb}, \mathrm{K}$ and $\mathrm{Al}$; not shown) display broadly similar average values and ranges in the black layers as compared to the bulk sediment. Si concentrations are higher in the bulk sediment, in agreement with higher diatom abundances. The elements which show the largest relative differences between black layers and bulk sediment are $\mathrm{Fe}(60 \%$ higher in the black layers) and $\mathrm{P}$ (109\% higher). S concentrations and Mo/ $\mathrm{Al}$ ratios are comparable in both types of samples, while As shows about $30 \%$ higher concentrations in the black layers. Note that element concentrations in the black layer samples are compared to bulk sediment samples including black layers. The differences in element concentrations between black layers and the surrounding clay gyttja could therefore be larger than the presented values.
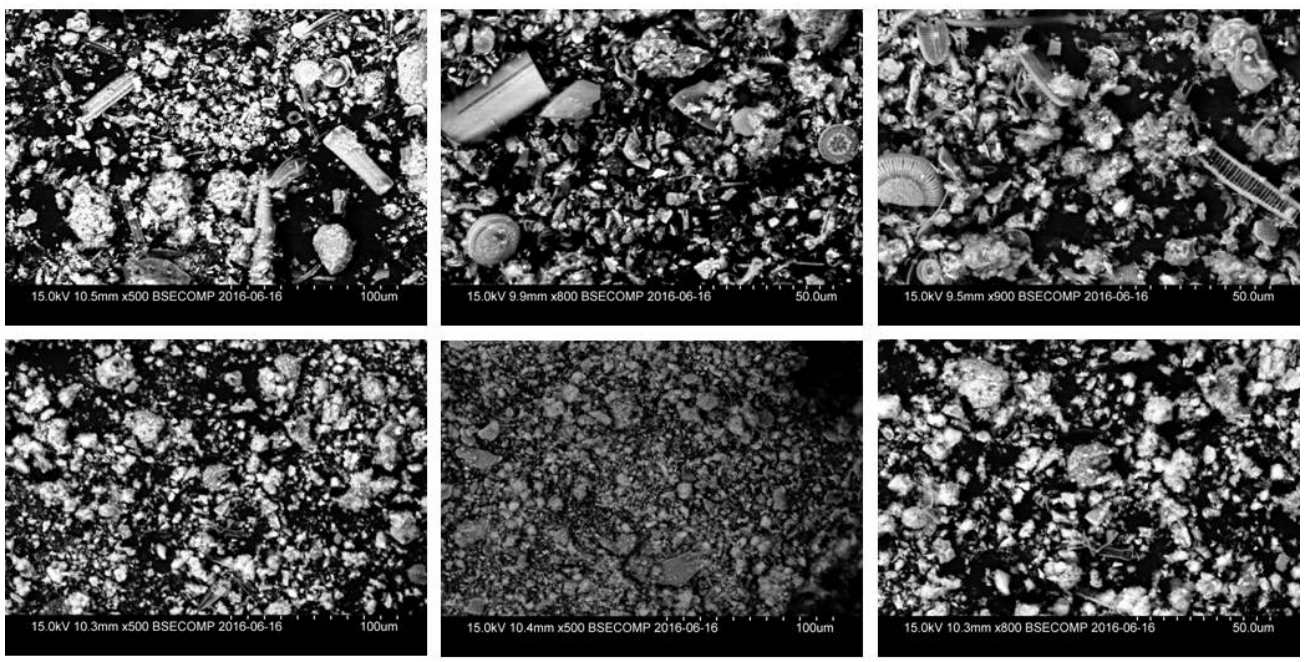

Figure 10. Examples of scanning electron microscope (SEM) images of the dominating clay gyttja in lithological Unit III (top row) and of intercalated black layers (bottom row). Autochthonous biogenic components like diatoms are abundant in the clay gyttja but rare in the black layers.

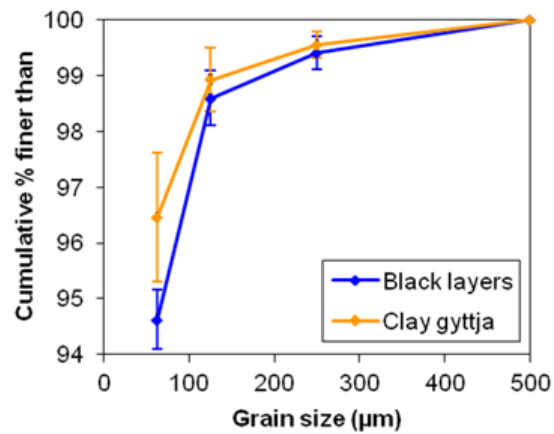

(a)
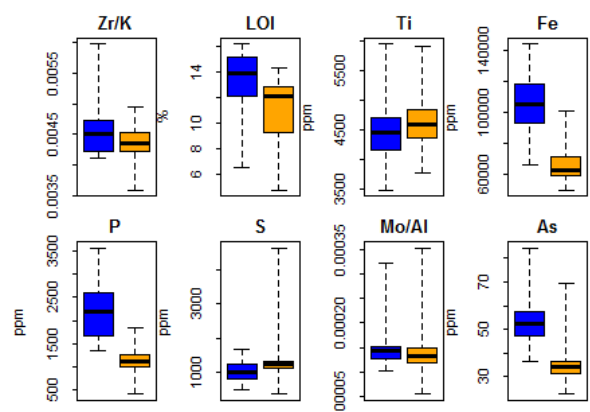

(b)

Figure 11. (a) Grain size distributions of six black layer and six clay gyttja samples sieved with 500, 250, 125 and $63 \mu \mathrm{m}$ meshes. Error bars indicate the range of values for each grain size class. (b) Element concentrations and ratios as well as organic matter content (LOI) of 14 pairs of black layer (blue) and surrounding bulk sediment samples (orange) between 20 and $354 \mathrm{~cm}$ depth. This interval was chosen to exclude Unit II, which has no black layers and to exclude the uppermost part of the sediment sequence, which is characterized by prominent peaks in many elements due to anthropogenic impact. The black horizontal lines represent the medians, the bottom and top of the boxes the lower and upper quartiles, respectively. The whiskers extend to the minimum and maximum values. 
The frequency of occurrence of the 335 black layers is variable throughout the sediment sequence (Figure 12). There is a slight increase around $6000 \mathrm{cal} \mathrm{yr} \mathrm{BP}$ and a marked augmentation between 3600 and $1800 \mathrm{cal} \mathrm{yr} \mathrm{BP,} \mathrm{with} \mathrm{a} \mathrm{peak} \mathrm{around} 2600 \mathrm{cal} \mathrm{yr} \mathrm{BP}$. The second increase is also characterized by a clear increase in sediment accumulation rate (Figure 12). Throughout the sediment sequence the average thickness of the black layers does not vary significantly.

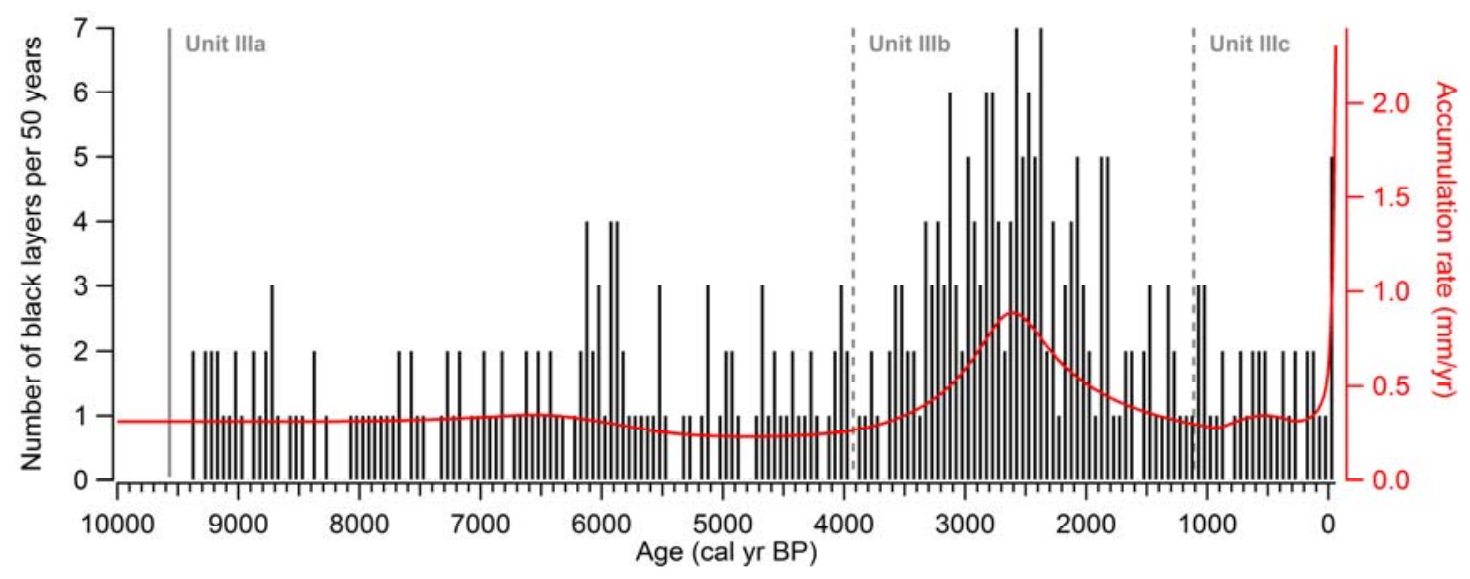

Figure 12. Numbers of black layers per 50-year interval in the STO14 sediment sequence (black bars) and accumulation rate (red curve).

\section{Discussion}

\subsection{Deglaciation and Early Postglacial Lake Development (Lithological Units I and II)}

In the Jämtland region, the last deglaciation proceeded well into the early Holocene. According to the age model, lacustrine sedimentation in Storsjön began at $9800 \pm 205 \mathrm{cal}$ yr BP (Unit I-II boundary), with a dominant glacial influence on the lake until $9550 \pm 200 \mathrm{cal}$ yr BP (Unit II-III boundary). This temporal framework is in general agreement with previously published estimates of the regional ice recession chronology (reviewed e.g., by [77]), which are based on radiocarbon dates from the basal parts of peat deposits, varve-dated shifts in lacustrine sedimentation [78], or cosmogenic nuclide dates [79].

As the ice sheet retreated from the Storsjön area, large bodies of stagnant ice remained. The landscape is characterized by dead-ice topography and numerous small lakes and the occurrence of ice-dammed lakes has been well documented [78,80,81]. Ice-dammed lakes form when ice margins block the natural drainage of a catchment, leaving behind geomorphological evidence such as shorelines, perched deltas, or overflow channels [77]. The shorelines at Frösön Island, 5 km NE of our sampling site, point to the formation of an extensive ice-dammed lake as the ice sheet was breaking up [78]. The general seismic stratigraphy of the lake, with outcropping bedrock on the lake floor and sediments of variable thickness and acoustic facies, is consistent with this interpretation.

Unit I of the STO14 sediment sequence is dominated by diamictic sediments of glacial origin. The intermittent occurrences of fine-grained, partly laminated sediments (Units Ic and Ie, Figure S1) likely represent temporary phases of glaciolacustrine sediment deposition. However, as these stratigraphic intervals lack organic matter, the timing and duration of these temporary lake phases could not be determined through radiocarbon dating. Due to their presumably different deposition rates as compared to the postglacial lacustrine sedimentation, an extrapolation of our age model through Unit I would be inappropriate. The seismic unit SU1, corresponding to Unit I, shows several acoustic facies with highly variable thicknesses and acoustic amplitudes (Figure 3). These are typical for diamictic deposits in large lakes of glacial origin [82-84].

At the transition from Unit I to II, a lake basin began to form, although the sedimentation was still strongly influenced by glacial activity in the catchment. Without stabilizing vegetation, strong 
fluvial, glacial and glaciofluvial erosion led to high accumulation rates following the deglaciation. The sediments of Unit II are dominantly minerogenic, with negligible organic matter content, high concentrations of lithogenic elements (Figures 5 and 8) and a mineral magnetic signature consistent with a predominantly detrital source (Figure 9). The finely laminated clays of Unit II are interpreted to represent glaciolacustrine varves, although microsedimentological analyses and independent chronological information for the bottom and top of Unit II would be needed to confirm the annual nature of the laminae. Dark-light layer couplets (varves) of glaciolacustrine sediments form in proglacial lake environments due to seasonal variations in erosion, transport and deposition processes. Light layers represent periods of enhanced meltwater discharge during the warm season, transporting coarser minerogenic material in suspension from the catchment into the lake. Dark layers are composed of very fine clay particles deposited during winter when the meltwater flux into the lake is clearly reduced and within-lake currents diminish under ice cover $[66,85,86]$. The varves in Unit II are preserved despite the supposed oxic conditions inferred from low Mo/Al ratios, because the dominant detrital sedimentation and cold temperatures prevented the establishment of burrowing biota. Unit II corresponds to the very high amplitude seismic facies of seismic unit SU2, characteristic for sediments deposited by glacial meltwater supply in an ice-contact lake [82,83].

\subsection{Lake and Catchment Processes During the Holocene (Lithological Unit III)}

At the transition from Unit II to Unit III ( $9550 \pm 200 \mathrm{cal}$ yr BP) the laminated clay is replaced by a more organic-rich clay gyttja, which is broadly similar to the present-day sediment facies. This transition coincides with major changes in chemical, mineral magnetic and acoustic parameters, which are linked to substantially altered in-lake processes and sedimentation conditions. An increase in grain size is indicated by increasing $\mathrm{Zr} / \mathrm{K}$ ratios [68], possibly corroborated by an increase in water content (Figures 5 and 8). The increase in grain size may be related to the cessation of the direct influence of glacial activity in the basin, which can be assumed to have led to primarily clay deposition at the distal position represented by our coring site and replacement with mineral matter of predominantly fluvial origin from the wider catchment.

The sharp drop in Ca concentration at the top of Unit II also reflects changes in catchment erosion processes influencing the sediment source. The dominant source of $\mathrm{Ca}$ is detrital input rather than biogenic precipitation. Throughout Unit II, glacial erosion and runoff on the newly exposed bedrock contributed clastic carbonate from the calcareous bedrock, which is mainly found S and E of the lake. In contrast, during deposition of Unit III, the lake received more input from the main inflow and the catchment NW of the lake, which has little carbonate bedrock. Furthermore, glacial activity provided fresh mechanically eroded bedrock material in Unit II, whereas Unit III is dominated by fluvial erosion of soils where carbonates were already dissolved.

The Unit II-III transition is also marked by abrupt increases in $\mathrm{S}$ concentration and $\mathrm{Mo} / \mathrm{Al}$ ratios (Figure 8) and by the potential formation of the magnetic iron sulphide greigite (high SIRM/ ; Figure 9). The $\mathrm{Mo} / \mathrm{Al}$ peak can be explained by lowered oxygen levels in the interstitial water $[69,70]$, caused by the increased primary production (LOI increase, Figure 5) and consequent oxygen consumption by bacterial respiration. This in turn forced primary biota to reduce sulphate as an energy source, a process with high affinity for Mo enrichment [87]. The subsequent decrease in the Mo/Al ratio therefore represents the return of oxygenated interstitial water conditions, perhaps due to increasing circulation in the basin.

Following the Unit II-III transition, the period of ca. 9550 to 4000 cal yr BP (Subunit IIIa) is characterized by a steady decrease in the concentrations of lithogenic elements, which is probably mainly a dilution effect, as organic matter shows a parallel increase (Figure 5). The input of terrestrial organic matter into the lake started to rise with the progressive development of soils and vegetation in the catchment, likely advancing to higher altitudes during this period $[11,88]$. Furthermore, warming temperatures led to increased organic productivity in the lake, as reflected by the probable introduction of magnetotactic bacteria (increase in $\mathrm{K}_{\mathrm{ARM}} / \mathrm{SIRM}$ and $\mathrm{MDF}_{\mathrm{ARM}}$; Figure 9) and to an increase in $\mathrm{Si}$ 
concentrations (Figure 8) through elevated biogenic silica production, predominantly from diatoms, a sediment component identified in the SEM images (Figure 10).

Subunit IIIb (ca. 4000 to 1100 cal yr BP) is characterized by largely constant lithogenic element concentrations, organic matter content and mineral magnetic parameters and by the absence of $\mathrm{Mo} / \mathrm{Al}$ peaks, which indicates relatively stable environmental conditions.

The transition to Subunit IIIc at ca. $1100 \mathrm{cal} \mathrm{yr} \mathrm{BP} \mathrm{marks} \mathrm{the} \mathrm{onset} \mathrm{of} \mathrm{increasing} \mathrm{trends} \mathrm{in} \mathrm{several}$ lithogenic elements $(\mathrm{Zr}, \mathrm{Rb}, \mathrm{Ti}, \mathrm{Ca}, \mathrm{K}, \mathrm{Al})$ as well as an increase in magnetic grain sizes (detrital source) (Figures 8 and 9), which most likely reflects human impact on the lake related to slowly expanding agricultural activity on fertile soils in the vicinity. Little is known about the settlement and agrarian history of the Storsjön area, but historical data indicate an initial expansion phase in the 12th century CE, followed by widespread farm abandonment in the 14th century CE [89]. Pollen data from a site about $100 \mathrm{~km}$ to the south do not show any major agricultural expansion before the 16th century CE [90], in general agreement with enhanced input of lithogenic matter in our sediment sequence at about this stage. A more intense phase of human impact on the lake ecosystem was initiated in the 20th century $C E$ as evident from rising organic matter content and an associated, distinct increase in sediment accumulation rate (Figure 4). These changes were likely related to sewage delivery following urbanization and the use of fertilizers, as indicated by the recent increase in $\mathrm{P}$ concentration (Figure 8). This development led to the return of hypoxic conditions in interstitial waters at the coring site for the first time since the early Holocene, as evidenced by rising Mo/ $\mathrm{Al}$ ratios and S concentration, mounting further evidence of the last decades as a period of anomalous anthropogenic perturbation of previously largely unaffected aquatic ecosystems, even in relatively remote and resilient settings [91,92]. The strong increase in $\mathrm{Cu}$ concentration in the recent past (Figure 8) reflects airborne metal pollution related to mining and metallurgy [93] and broadly follows the trend of increasing $\mathrm{Pb}$ concentration (Figure 6).

\subsection{Palaeoenvironmental Significance of the Black Layers}

\subsubsection{Sediment Deposition at the Coring Site}

The sediments in Unit III at our coring site constitute the levee of a drift deposit located northward of a $200 \mathrm{~m}$ wide channel where seismic unit 1 (SU1) is outcropping (Figures 2 and 3), indicating that sedimentation is controlled by deep-water circulation processes [94]. Drifts and moats in lakes, or lacustrine contourite deposits and channels, have previously been documented by seismic profiles and sediment cores in large lakes exposed to strong winds, e.g., Lake Superior in North America [41], Lago Cardiel in Argentina [39] and Lake Geneva in Switzerland [35].

Large tributary flood events can develop long-lasting hyperpycnal flows in both marine and lacustrine environments [31,95]. In lakes, the resulting hyperpycnal flood deposits are layers of variable thickness (millimetres to centimetres), essentially composed of clastic material and rich in organic matter of terrestrial origin [26]. In proximal deltaic environments, the deposits are graded and silty, whereas in deeper distal basins, they are commonly sharp-based and very fine-grained (clayey-silty) $[23,31,96]$. Hyperpycnal flood deposits in large lakes are frequently documented in deltaic environments and in distal fan lobes from the last deglaciation, or from Holocene cold and wet periods, such as the Little Ice Age, associated with alpine glacier fluctuations and enhanced glaciofluvial regimes [19]. In the case of Storsjön, snowmelt floods could carry fine-grained suspended sediment load from the catchment and develop long-lasting hyperpycnal flows when entering the lake basin. These turbulent flows follow the lake floor morphology and are exposed to the Coriolis force. If they occur frequently, they can control the distribution of clastic sediments in the lake and form channel-levee systems, such as the one we cored at site STO14. Hence, we hypothesize that the observed black layers represent distal snowmelt flood layers deposited in lacustrine contourites. 


\subsubsection{Mechanisms of Black Layer Formation and Preservation}

The formation of black layers in sediments linked to low oxygen concentrations in bottom waters or surface sediments has been documented in a number of contexts. Black bands of iron sulphide have been observed in sediments of the Great Lakes deposited during the Holocene Thermal Optimum at ca. 8000 to $4000 \mathrm{cal}$ yr BP [97]. These layers are thought to represent events of hypoxic or anoxic conditions caused by climate warming that led to intensified stratification and the absence of the seasonal turnover. In sediments along the southern coast of Finland, black layers containing iron sulphides have been identified, corresponding to anoxic and reduced bottom water conditions due to temperature and salinity stratification [98]. Anoxic conditions in surface sediments can also be caused by enhanced sedimentation after discharge events, when rapid burial prevents exchange processes at the sediment-water interface [99].

The black layers in the Storsjön sediments reflect brief and transient events of increased fluvial inflow and sediment transport into the lake, caused by strong snowmelt floods. These meltwater floods generally occur in May/June in the region and can cause soil erosion and increased sediment accumulation and grain size, as shown by studies of varved sediments in Scandinavian lakes [100-102]. The larger grain size of the black layers as compared to the surrounding clay gyttja is only minor, probably because of the distal location of the coring site, $30 \mathrm{~km}$ from the lake's main inflow (Figure 1). It could be argued that the black layer itself is not the flood layer but rather that it was present at the sediment surface before the spring snowmelt flood. A rapid burial by flood deposits would reduce the exchange with bottom water, leading to rapid oxygen depletion and preservation of the black colour. This would lead to the higher black layer frequency during times of higher accumulation rates. However, this explanation is contradicted by the larger grain size and the absence of diatoms and other macroscopic organism remains in the black layers (Figure 10), which is also reflected by the low Si concentrations (Figure 11). Together with the higher organic matter contents, this also suggests that the black layer material originates from the catchment rather than from re-distribution of previously deposited sediments by lake currents. We therefore assume that the black layer itself represents a rapid, event-like deposition of allochthonous material.

Snowmelt floods lead to an increased delivery of terrestrial organic detritus from the catchment and perhaps augment the oxygenation of the lake water and consequently the primary production in the lake. The increased accumulation of organic matter is initially followed by decomposition and, due to the oxygen consumption by bacterial respiration, eventually leads to hypoxic or anoxic conditions in the interstitial water. Therefore, not all organic matter is decomposed, leading to the relatively high organic matter content of the black layers (Figure 11).

The black colour of the layers, indicating the presence of finely distributed pyrite $\left(\mathrm{FeS}_{2}\right)$ formed under anoxic conditions, changed to brown due to oxidation of $\mathrm{FeS}_{2}$ on opening the cores. Before that, the elevated organic matter content kept the interstitial water anaerobic. The significantly higher As concentration of the black layers is an indicator of pyrite $[103,104]$. The anoxic conditions in the black layers are further confirmed by concretions of vivianite $\left[\left(\mathrm{Fe}_{3}\left(\mathrm{PO}_{4}\right)_{2} \cdot 8 \mathrm{H}_{2} \mathrm{O}\right)\right][105-107]$, which are visible around macroscopic plant remains in some thicker black layers. Fe and $\mathrm{P}$, both constituents of vivianite, also exhibit significantly higher concentrations in the black layers. Note that the supposed anoxic conditions occur in the sediment and not in the water. Cold temperatures and wind likely prevent the establishment of stable stratification and related anoxic bottom water conditions in Lake Storsjön.

\subsubsection{Relations to Climate and Vegetation Changes}

The processes of erosion and transport of material in the drainage basin that lead to the deposition of black layers depend on the amount of snowfall during winter and the rate of temperature increase in spring, as well as, in the longer term, the properties of the land surface [102]. Variations in black layer occurrence therefore depend on land cover (vegetation) changes, flood frequency (climate), or a combination of both. 
The type of land cover determines the intensity of catchment erosion during snowmelt floods. A decrease in vegetation cover would lead to destabilized soils and consequently enhanced soil erosion even if the magnitude of meltwater floods does not change. A gradual change to cooler and/or wetter conditions has been observed in Scandinavia at the end of the Holocene Thermal Maximum and the onset of the Neoglacial Period around $4000 \mathrm{cal}$ yr BP, with a thicker snow cover in the Scandes Mountains that melted later in the year [11,14]. This climatic change caused a tree line descent in the Scandes Mountains $[3,108,109]$ including the Storsjön catchment $[11,88]$, as well as an increased formation of peatlands [110]. A lowering of the tree line has likely destabilized soils at high elevations in the Storsjön catchment and increased erosion during snowmelt floods, triggering the mechanisms of black layer formation described above. Consequently, an increase in black layer frequency is observed from about $3500 \mathrm{cal}$ yr BP onward.

Additionally, black layer frequency may increase with a more frequent occurrence of strong snowmelt floods, caused by enhanced snow accumulation in the winter, possibly accompanied by a faster warming and melting of snow in the spring as well as spring rainfall. This was the case e.g., during the 1995 spring flood, the largest in central Sweden in the 20th century: A long winter caused snow accumulation in mountain regions that was $20-50 \%$ above average and a rapid increase of temperatures in the spring, accompanied by rainfall, led to the onset of snowmelt almost simultaneously in mountains and lowlands [111]. Such an intense meltwater pulse would cause stronger erosion and trigger the processes described in Section 4.3.2. The factors controlling the amount of snow accumulated during winters and the magnitude of subsequent spring meltwater floods are complex. While a generally warmer climate could increase the total amount of precipitation, it would at the same time shorten the period of the year when precipitation falls as snow, as demonstrated for the River Ångermanälven catchment north of the Storsjön catchment [112]. Lake sediment records from southern Norway reveal a co-variability between winter precipitation and floods on millennial time scales but climate projections indicate a decrease in flood frequency with future warming, as this will mitigate that net effect of a wetter climate regime [113].

The phase of maximum snowmelt flood frequency inferred from the Storsjön sediments (Figure 12) coincides, with a grand solar minimum around 2750-2550 cal yr BP. Shifts in atmospheric circulation associated with the solar forcing caused abrupt regional climate change [114], which has been detected in a number of European palaeoclimate records, e.g., [115-120]. Scandinavian climate is dominantly controlled by large-scale atmospheric circulation dynamics in the North Atlantic region [12,121,122]. For example, variations in the North Atlantic Oscillation (NAO) index explain 55\% of the variance of streamflow in Norway, with a positive NAO state leading to warm and wet conditions [123]. Model simulations suggest that solar radiation minima lead to the predominance of a negative NAO phase, the driver of cold winters in northern Europe [124]. A reconstruction based on lake sediments from Greenland suggests that negative NAO conditions characterized the period from 2800 to $2600 \mathrm{cal} \mathrm{yr}$ BP [125], broadly consistent with similar evidence from North Central Sweden [14] and expanding mountain glaciers in southern Norway [126].

Against the background of increasing availability of erodible soil material brought about by a tree line descent in the Storsjön catchment from 3500 cal yr BP onward, the effects of the solar minimum and associated atmospheric circulation changes may have caused the peak in flood layers around $2600 \mathrm{cal}$ yr BP, with relatively cold winters in northern Europe leading to a longer period of snow accumulation and a higher intensity of subsequent snowmelt floods.

\section{Conclusions}

We have investigated the distribution as well as the chemical and mineral magnetic properties of sediments in Lake Storsjön and explored their palaeoclimatic significance. The bedrock topography and geometry of the basin infill were mapped for the first time. It is important to understand the highly uneven distribution of contourite deposits in this large lake for future sedimentological studies. The processes of deglaciation and early postglacial lake development inferred from the 
Storsjön sediment record are coherent with other geological evidence from the region. Lake Storsjön began to form about $9800 \mathrm{cal} \mathrm{yr} \mathrm{BP}$ and significant glacial influence persisted in the catchment for another 250 years. Throughout most of the Holocene, geochemical and mineral magnetic proxies indicate relatively stable environmental conditions in the lake. Since $1100 \mathrm{cal}$ yr BP, human influence becomes visible in the sediments through unprecedented proxy variation in a Holocene perspective, with potentially significant impact on the lake ecosystem during the 20th century.

Hyperpycnal flows following snowmelt flood events led to the deposition of contourites and the frequent formation of black layers containing iron sulphide through the enhanced input of terrestrial organic detritus. The processes of erosion and transport of material that lead to the deposition of black layers depend on two main factors: the amount of snow accumulated during the winter and the properties of the land surface. The increased occurrence of black layers between 3600 and $1800 \mathrm{cal}$ yr BP likely reflects vegetation changes, as a tree line descent in the catchment destabilized soils and provided increased amounts of erodible organic soil material. The peak in black layer occurrence about $2600 \mathrm{cal}$ yr BP coincides with a grand solar minimum. The associated predominance of the negative phase of the North Atlantic Oscillation caused relatively cold winters in northern Europe, increased snow accumulation and more intense snowmelt floods. The flood history reconstructed from the sediments of this large lake therefore reflects not only local catchment-scale processes but also large-scale climatic change.

Supplementary Materials: The following are available online at www.mdpi.com/2571-550X/1/1/2/s1, Figure S1: Schematic overview of the sediment cores from Lake Storsjön. Data are available at https:/ / www.ncdc.noaa. gov/paleo/study/23372.

Acknowledgments: We are grateful to S.-Å. Jonsson and M. Oginder for excellent fieldwork logistics and to L. Johansson, B. Lougheed and I. Snowball for support with analytical procedures. We also thank two anonymous reviewers for their constructive comments. This research was funded by the Swedish Research Council as part of the French-Swedish Common Research and Training Programme on Climate and the Environment (grant No. 349-2012-6291).

Author Contributions: D.H. and U.v.G. conceived and designed the study. D.H., E.C., E.R., J.R. and U.v.G. carried out the fieldwork. I.L., D.H., J.-P.D., A.N. and J.R. performed the laboratory analyses. I.L., D.H., E.C., M.C., A.N., J.R. and U.v.G. interpreted the data. I.L. wrote the paper with contributions from D.H., E.C., M.C., A.N. and U.v.G.

Conflicts of Interest: The authors declare no conflict of interest.

\section{References}

1. Nesje, A.; Matthews, J.A.; Dahl, S.O.; Berrisford, M.S.; Andersson, C. Holocene glacier fluctuations of Flatebreen and winter precipitation changes in the Jostedalsbreen region, western Norway, based on glaciolacustrine sediment records. Holocene 2001, 11, 267-280. [CrossRef]

2. Hammarlund, D.; Björck, S.; Buchardt, B.; Israelson, C.; Thomsen, C.T. Rapid hydrological changes during the Holocene revealed by stable isotope records of lacustrine carbonates from Lake Igelsjön, southern Sweden. Quat. Sci. Rev. 2003, 22, 353-370. [CrossRef]

3. Bjune, A.E.; Birks, H.J.B.; Seppä, H. Holocene vegetation and climate history on a continental-oceanic transect in northern Fennoscandia based on pollen and plant macrofossils. Boreas 2004, 33, 211-223. [CrossRef]

4. Velle, G.; Brooks, S.J.; Birks, H.J.B.; Willassen, E. Chironomids as a tool for inferring Holocene climate: An assessment based on six sites in southern Scandinavia. Quat. Sci. Rev. 2005, 24, 1429-1462. [CrossRef]

5. Andersson, S.; Rosqvist, G.; leng, M.J.; Wastegård, S.; Blaauw, M. Late Holocene climate change in central Sweden inferred from lacustrine stable isotope data. J. Quat. Sci. 2010, 25, 1305-1316. [CrossRef]

6. Vasskog, K.; Nesje, A.; Støren, E.N.; Waldmann, N.; Chapron, E.; Ariztegui, D. A Holocene record of snow-avalanche and flood activity reconstructed from a lacustrine sedimentary sequence in Oldevatnet, western Norway. Holocene 2011, 21, 597-614. [CrossRef]

7. Muschitiello, F.; Schwark, L.; Wohlfarth, B.; Sturm, C.; Hammarlund, D. New evidence of Holocene atmospheric circulation dynamics based on lake sediments from southern Sweden: A link to the Siberian High. Quat. Sci. Rev. 2013, 77, 113-124. [CrossRef] 
8. Rosén, P.; Segerström, U.; Eriksson, L.; Renberg, I.; Birks, H.J.B. Holocene climatic change reconstructed from diatoms, chironomids, pollen and near-infrared spectroscopy at an alpine lake (Sjuodjijaure) in northern Sweden. Holocene 2001, 11, 551-562. [CrossRef]

9. Bigler, C.; Larocque, I.; Peglar, S.M.; Birks, H.J.B.; Hall, R.I. Quantitative multiproxy assessment of long-term patterns of Holocene environmental change from a small lake near Abisko, northern Sweden. Holocene 2002, 12, 481-496. [CrossRef]

10. Hammarlund, D.; Barnekow, L.; Birks, H.J.B.; Buchardt, B.; Edwards, T.W.D. Holocene changes in atmospheric circulation recorded in the oxygen-isotope stratigraphy of lacustrine carbonates from northern Sweden. Holocene 2002, 12, 339-351. [CrossRef]

11. Hammarlund, D.; Velle, G.; Wolfe, B.B.; Edwards, T.W.D.; Barnekow, L.; Bergman, J.; Holmgren, S.; Lamme, S.; Snowball, I.; Wohlfarth, B.; et al. Palaeolimnological and sedimentary responses to Holocene forest retreat in the Scandes Mountains, west-central Sweden. Holocene 2004, 14, 862-876. [CrossRef]

12. Jonsson, C.E.; Andersson, S.; Rosqvist, G.C.; Leng, M.J. Reconstructing past atmospheric circulation changes using oxygen isotopes in lake sediments from Sweden. Clim. Past 2010, 6, 49-62. [CrossRef]

13. Reuss, N.S.; Hammarlund, D.; Rundgren, M.; Segerström, U.; Eriksson, L.; Rosén, P. Lake Ecosystem Responses to Holocene Climate Change at the Subarctic Tree-Line in Northern Sweden. Ecosystems 2010, 13, 393-409. [CrossRef]

14. St. Amour, N.A.; Hammarlund, D.; Edwards, T.W.D.; Wolfe, B.B. New insights into Holocene atmospheric circulation dynamics in central Scandinavia inferred from oxygen-isotope records of lake-sediment cellulose. Boreas 2010, 39, 770-782. [CrossRef]

15. Meyer-Jacob, C.; Bindler, R.; Bigler, C.; Leng, M.J.; Lowick, S.E.; Vogel, H. Regional Holocene climate and landscape changes recorded in the large subarctic lake Torneträsk, N Fennoscandia. Palaeogeogr. Palaeoclimatol. Palaeoecol. 2017. [CrossRef]

16. Von Grafenstein, U.; Erlenkeuser, H.; Brauer, A.; Jouzel, J.; Johnsen, S. A Mid-European Decadal Isotope-Climate Record from 15,500 to 5000 Years B.P. Science 1999, 284, 1654-1657. [CrossRef] [PubMed]

17. Talbot, M.R.; Lærdal, T. The Late Pleistocene-Holocene palaeolimnology of Lake Victoria, East Africa, based upon elemental and isotopic analyses of sedimentary organic matter. J. Paleolimnol. 2000, 23, 141-164. [CrossRef]

18. Arnaud, F.; Revel, M.; Chapron, E.; Desmet, M.; Tribovillard, N. 7200 years of Rhône River flooding activity in Lake Le Bourget, France: A high-resolution sediment record of NW Alps hydrology. Holocene 2005, 15, 420-428. [CrossRef]

19. Chapron, E.; Arnaud, F.; Noël, H.; Revel, M.; Desmet, M.; Perdereau, L. Rhone River flood deposits in Lake Le Bourget: A proxy for Holocene environmental changes in the NW Alps, France. Boreas 2005, 34, 404-416. [CrossRef]

20. Statens Offentliga Utredningar (SOU). Sweden Facing Climate Change-Threats and Opportunities; Swedish Government Official Reports; SOU: Stockholm, Sweden, 2007.

21. Kochel, R.C.; Baker, V.R. Paleoflood Hydrology. Science 1982, 215, 353-361. [CrossRef] [PubMed]

22. Mudelsee, M.; Börngen, M.; Tetzlaff, G.; Grünewald, U. No upward trends in the occurrence of extreme floods in central Europe. Nature 2003, 425, 166-169. [CrossRef] [PubMed]

23. Debret, M.; Chapron, E.; Desmet, M.; Rolland-Revel, M.; Magand, O.; Trentesaux, A.; Bout-Roumazeille, V.; Nomade, J.; Arnaud, F. North western Alps Holocene paleohydrology recorded by flooding activity in Lake Le Bourget, France. Quat. Sci. Rev. 2010, 29, 2185-2200. [CrossRef]

24. Støren, E.N.; Kolstad, E.W.; Paasche, Ø. Linking past flood frequencies in Norway to regional atmospheric circulation anomalies. J. Quat. Sci. 2012, 27, 71-80. [CrossRef]

25. Czymzik, M.; Muscheler, R.; Brauer, A. Solar modulation of flood frequency in central Europe during spring and summer on interannual to multi-centennial timescales. Clim. Past 2016, 12, 799-805. [CrossRef]

26. Simonneau, A.; Chapron, E.; Vannière, B.; Wirth, S.B.; Gilli, A.; Di Giovanni, C.; Anselmetti, F.S.; Desmet, M.; Magny, M. Mass-movement and flood-induced deposits in Lake Ledro, southern Alps, Italy: Implications for Holocene palaeohydrology and natural hazards. Clim. Past 2013, 9, 825-840. [CrossRef]

27. Vannière, B.; Magny, M.; Joannin, S.; Simonneau, A.; Wirth, S.B.; Hamann, Y.; Chapron, E.; Gilli, A.; Desmet, M.; Anselmetti, F.S. Orbital changes, variation in solar activity and increased anthropogenic activities: Controls on the Holocene flood frequency in the Lake Ledro area, Northern Italy. Clim. Past 2013, 9, 1193-1209. [CrossRef] 
28. Wilhelm, B.; Arnaud, F.; Sabatier, P.; Magand, O.; Chapron, E.; Courp, T.; Tachikawa, K.; Fanget, B.; Malet, E.; Pignol, C.; et al. Palaeoflood activity and climate change over the last 1400 years recorded by lake sediments in the north-west European Alps. J. Quat. Sci. 2013, 28, 189-199. [CrossRef]

29. Wirth, S.B.; Glur, L.; Gilli, A.; Anselmetti, F.S. Holocene flood frequency across the Central Alps-Solar forcing and evidence for variations in North Atlantic atmospheric circulation. Quat. Sci. Rev. 2013, 80, 112-128. [CrossRef]

30. Sturm, M.; Matter, A. Turbidites and Varves in Lake Brienz (Switzerland): Deposition of Clastic Detritus by Density Currents. In Modern and Ancient Lake Sediments; Matter, A., Tucker, M.E., Eds.; Blackwell: Oxford, UK, 1978; pp. 147-168. ISBN 9781444303698.

31. Mulder, T.; Chapron, E. Flood deposits in continental and marine environments: Character and significance. In Sediment Tranfer from Shelf to Deep Water-Revisiting the Delivery System; Slatt, R.M., Zavala, C., Eds.; American Association of Petroleum Geologists: Tulsa, OK, USA, 2011; pp. 1-30.

32. Czymzik, M.; Dulski, P.; Plessen, B.; von Grafenstein, U.; Naumann, R.; Brauer, A. A 450 year record of spring-summer flood layers in annually laminated sediments from Lake Ammersee (southern Germany). Water Resour. Res. 2010, 46. [CrossRef]

33. Schröder, H.G.; Wessels, M.; Niessen, F. Acoustic facies and depositional structures of Lake Constance. Ergebnisse der Limnolog. 1999, 53, 351-368.

34. Schneider, J.L.; Pollet, N.; Chapron, E.; Wessels, M.; Wassmer, P. Signature of Rhine Valley sturzstrom dam failures in Holocene sediments of Lake Constance, Germany. Sediment. Geol. 2004, 169, 75-91. [CrossRef]

35. Girardclos, S.; Baster, I.; Wildi, W.; Pugin, A.; Rachoud-Schneider, A.-M. Bottom-current and wind-pattern changes as indicated by Late Glacial and Holocene sediments from western Lake Geneva (Switzerland). In Lake Systems from the Ice Age to Industrial Time; Birkhäuser Basel: Basel, Switzerland, 2003; pp. 39-48.

36. Girardclos, S.; Fiore, J.; Rachoud-Schneider, A.-M.; Baster, I.; Wildo, W. Petit-Lac (western Lake Geneva) environment and climate history from deglaciation to the present: A synthesis. Boreas 2005, 34, 417-433. [CrossRef]

37. Chapron, E.; Van Rensbergen, P.; De Batist, M.; Beck, C.; Henriet, J.P. Fluid-escape features as a precursor of a large sublacustrine sediment slide in Lake Le Bourget, NW Alps, France. Terra Nova 2004, 16, 305-311. [CrossRef]

38. Gilli, A.; Anselmetti, F.S.; Ariztegui, D.; Beres, M.; McKenzie, J.A.; Markgraf, V. Seismic stratigraphy, buried beach ridges and contourite drifts: The Late Quaternary history of the closed Lago Cardiel basin, Argentina (49 S). Sedimentology 2005, 52, 1-23. [CrossRef]

39. Gilli, A.; Ariztegui, D.; Anselmetti, F.S.; McKenzie, J.A.; Markgraf, V.; Hajdas, I.; McCulloch, R.D. Mid-Holocene strengthening of the Southern Westerlies in South America-Sedimentological evidences from Lago Cardiel, Argentina (49 ${ }^{\circ}$ S). Glob. Planet. Chang. 2005, 49, 75-93. [CrossRef]

40. Kremer, K.; Corella, J.P.; Hilbe, M.; Marillier, F.; Dupuy, D.; Zenhäusern, G.; Girardclos, S. Changes in distal sedimentation regime of the Rhone delta system controlled by subaquatic channels (Lake Geneva, Switzerland/France). Mar. Geol. 2015, 370, 125-135. [CrossRef]

41. Johnson, T.C. Late-glacial and postglacial sedimentation in Lake Superior based on seismic-reflection profiles. Quat. Res. 1980, 13, 380-391. [CrossRef]

42. Johnson, T.C. Sedimentary processes and signals of past climate change in the large lakes of the East African Rift Valley. In The Limnology, Climatology and Paleoclimatology of the East African Lakes; Johnson, T.C., Odada, E.O., Eds.; Gordon \& Breach: Amsterdam, The Netherlands, 1996; p. 664.

43. Ceramicola, S.; Rebesco, M.; De Batist, M.; Khlystov, O. Seismic evidence of small-scale lacustrine drifts in Lake Baikal (Russia). Mar. Geophys. Res. 2001, 22, 445-464. [CrossRef]

44. Lundqvist, J. Weichsel-istidens huvudfas. In Berg och jord; Fredén, C., Ed.; Sveriges Nationalatlas: Stockholm, Sweden, 2009; p. 208.

45. Hallberg, K.; Wänström, M.; Edman, A. Circulationsmodell Storsjön (Circulation Model Storsjön); SMHI Report No. 2015-17; Swedish Meteorological and Hydrological Institute: Stockholm, Sweden, 2015.

46. SMHI (Swedish Meteorological and Hydrological Institute). Vattenwebb. Available online: vattenwebb. smhi.se (accessed on 15 May 2017).

47. Renberg, I.; Hansson, H. Freeze corer No. 3 for lake sediments. J. Paleolimnol. 2010, 44, 731-736. [CrossRef] 
48. Cottereau, E.; Arnold, M.; Moreau, C.; Baqué, D.; Bavay, D.; Caffy, I.; Comby, C.; Dumoulin, J.-P.; Hain, S.; Perron, M.; et al. Artemis, the New 14C AMS at LMC14 in Saclay, France. Radiocarbon 2007, 49, 291-299. [CrossRef]

49. Moreau, C.; Caffy, I.; Comby, C.; Delqué-Količ, E.; Dumoulin, J.-P.; Hain, S.; Quiles, A.; Setti, V.; Souprayen, C.; Thellier, B.; et al. Research and Development of the Artemis ${ }^{14} \mathrm{C}$ AMS Facility: Status Report. Radiocarbon 2013, 55, 331-337. [CrossRef]

50. Dumoulin, J.-P.; Comby-Zerbino, C.; Delqué-Količ, E.; Moreau, C.; Caffy, I.; Hain, S.; Perron, M.; Thellier, B.; Setti, V.; Berthier, B.; et al. Status Report on Sample Preparation Protocols Developed at the LMC14 Laboratory, Saclay, France: From Sample Collection to 14C AMS Measurement. Radiocarbon 2017, 59, 713-726. [CrossRef]

51. Reimer, P.; Bard, E.; Bayliss, A. IntCal13 and Marine13 radiocarbon age calibration curves 0-50,000 years cal BP. Radiocarbon 2013, 55, 1869-1887. [CrossRef]

52. Weiss, D.; Shotyk, W.; Appleby, P.G.; Kramers, J.D.; Cheburkin, A.K. Atmospheric Pb Deposition since the Industrial Revolution Recorded by Five Swiss Peat Profiles: Enrichment Factors, Fluxes, Isotopic Composition and Sources. Environ. Sci. Technol. 1999, 33, 1340-1352. [CrossRef]

53. Brännvall, M.-L.; Bindler, R.; Renberg, I.; Emteryd, O.; Bartnicki, J.; Billström, K. The Medieval metal industry was the cradle of modern large-scale atmospheric lead pollution in Northern Europe. Environ. Sci. Technol. 1999, 33, 4391-4395. [CrossRef]

54. Boës, X.; Rydberg, J.; Martinez-Cortizas, A.; Bindler, R.; Renberg, I. Evaluation of conservative lithogenic elements ( $\mathrm{Ti}, \mathrm{Zr}, \mathrm{Al}$, and $\mathrm{Rb}$ ) to study anthropogenic element enrichments in lake sediments. J. Paleolimnol. 2011, 46, 75-87. [CrossRef]

55. Cutshall, N.H.; Larsen, I.L.; Olsen, C.R. Direct analysis of ${ }^{210} \mathrm{~Pb}$ in sediment samples: Self-absorption corrections. Nucl. Instrum. Methods 1983, 306, 309-312. [CrossRef]

56. Blaauw, M. Methods and code for "classical" age-modelling of radiocarbon sequences. Quat. Geochronol. 2010, 5, 512-518. [CrossRef]

57. Heiri, O.; Lotter, A.; Lemcke, G. Loss on ignition as a method for estimating organic and carbonate content in sediments: Reproducibility and comparability of results. J. Paleolimnol. 2001, 25, 101-110. [CrossRef]

58. Vogel, H.; Wagner, B.; Rosén, P. Lake floor morphology and sediment architecture of lake Torneträsk, northern Sweden. Geogr. Ann. Ser. A Phys. Geogr. 2013, 95, 159-170. [CrossRef]

59. Ritchie, J.C.; McHenry, J.R. Application of Radioactive Fallout Cesium-137 for Measuring Soil Erosion and Sediment Accumulation Rates and Patterns: A Review. J. Environ. Qual. 1990, 19, 215-233. [CrossRef]

60. Jarvis, N.J.; Taylor, A.; Larsbo, M.; Etana, A.; Rosén, K. Modelling the effects of bioturbation on the re-distribution of ${ }^{137} \mathrm{Cs}$ in an undisturbed grassland soil. Eur. J. Soil Sci. 2010, 61, 24-34. [CrossRef]

61. Klaminder, J.; Appleby, P.; Crook, P.; Renberg, I. Post-deposition diffusion of ${ }^{137}$ Cs in lake sediment: Implications for radiocaesium dating. Sedimentology 2012, 59, 2259-2267. [CrossRef]

62. Renberg, I.; Persson, M.W.; Emteryd, O. Pre-industrial atmospheric lead contamination detected in Swedish lake sediments. Nature 1994, 368, 323-326. [CrossRef]

63. Renberg, I.; Bindler, R.; Brannvall, M.L. Using the historical atmospheric lead-deposition record as a chronological marker in sediment deposits in Europe. Holocene 2001, 11, 511-516. [CrossRef]

64. Bindler, R.; Renberg, I.; Rydberg, J.; Andrén, T. Widespread waterborne pollution in central Swedish lakes and the Baltic Sea from pre-industrial mining and metallurgy. Environ. Pollut. 2009, 157, 2132-2141. [CrossRef] [PubMed]

65. Andrén, T.; Björck, J.; Johnsen, S. Correlation of Swedish glacial varves with the Greenland (GRIP) oxygen isotope record. J. Quat. Sci. 1999, 14, 361-371. [CrossRef]

66. Petterson, G. Varved sediments in Sweden: A brief review. Geol. Soc. Lond. Spec. Publ. 1996, 116, 73-77. [CrossRef]

67. Cunningham, L.; Vogel, H.; Wennrich, V.; Juschus, O.; Nowaczyk, N.; Rosén, P. Amplified bioproductivity during Transition IV (332,000-342,000 years ago): Evidence from the geochemical record of Lake El'gygytgyn. Clim. Past 2013, 9, 679-686. [CrossRef]

68. Cuven, S.; Francus, P.; Lamoureux, S.F. Estimation of grain size variability with micro X-ray fluorescence in laminated lacustrine sediments, Cape Bounty, Canadian high arctic. J. Paleolimnol. 2010, 44, 803-817. [CrossRef] 
69. Dean, W.E.; Piper, D.Z.; Peterson, L.C. Molybdenum accumulation in Cariaco basin sediment over the past 24 k.y.: A record of water-column anoxia and climate. Geology 1999, 27, 507-510. [CrossRef]

70. Chappaz, A.; Gobeil, C.; Tessier, A. Geochemical and anthropogenic enrichments of Mo in sediments from perennially oxic and seasonally anoxic lakes in Eastern Canada. Geochim. Cosmochim. Acta 2008, 72, 170-184. [CrossRef]

71. Snowball, I.; Thompson, R. A stable chemical remanence in Holocene sediments. J. Geophys. Res. 1990, 95, 4471. [CrossRef]

72. Maher, B.A. Magnetic properties of some synthetic sub-micron magnetites. Geophys. J. Int. 1988, 94, 83-96. [CrossRef]

73. Oldfield, F. Toward the discrimination of fine-grained ferrimagnets by magnetic measurements in lake and near-shore marine sediments. J. Geophys. Res. Solid Earth 1994, 99, 9045-9050. [CrossRef]

74. Egli, R. Characterization of Individual Rock Magnetic Components by Analysis of Remanence Curves, 1. Unmixing Natural Sediments. Stud. Geophys. Geod. 2004, 48, 391-446. [CrossRef]

75. Moskowitz, B.M.; Frankel, R.B.; Bazylinski, D.A. Rock magnetic criteria for the detection of biogenic magnetite. Earth Planet. Sci. Lett. 1993, 120, 283-300. [CrossRef]

76. Snowball, I.; Zillén, L.; Sandgren, P. Bacterial magnetite in Swedish varved lake-sediments: A potential bio-marker of environmental change. Quat. Int. 2002, 88, 13-19. [CrossRef]

77. Stroeven, A.P.; Hättestrand, C.; Kleman, J.; Heyman, J.; Fabel, D.; Fredin, O.; Goodfellow, B.W.; Harbor, J.M.; Jansen, J.D.; Olsen, L.; et al. Deglaciation of Fennoscandia. Quat. Sci. Rev. 2016, 147, 91-121. [CrossRef]

78. Lundqvist, J. Isavsmältningens Förlopp i Jämtlands län; Sveriges Geologiska Undersökning: Uppsala, Sweden, 1973; Volume 66, p. 187.

79. Johnsen, T.F. Late Quaternary Ice Sheet History and Dynamics in Central and Southern Scandinavia. Ph.D. Thesis, Stockholm University, Stockholm, Sweden, 2010.

80. Lundqvist, J. Ice-lake types and deglaciation pattern along the Scandinavian mountain range. Boreas 1972, 1, 27-54. [CrossRef]

81. Borgström, I. Terrängformerna och den Glaciala Utvecklingen i Södra Fjällen; Stockholm University: Stockholm, Sweden, 1989.

82. Moscariello, A.; Pugin, A.; Wildi, W.; Beck, C.; Chapron, E.; De Batist, M.; Girardclos, S.; Ivy Ochs, S.; Rachoud-Schneider, A.M.; Signer, C.; et al. Déglaciation würmienne dans des conditions lacustres à la terminaison occidentale du bassin lémanique (Suisse occidentale et France). Eclogae Geol. Helv. 1998, 91, 185-201. [CrossRef]

83. Van Rensbergen, P.; De Batist, M.; Beck, C.; Manalt, F. High-resolution seismic stratigraphy of late quaternary fill of Lake Annecy (northwestern Alps): Evolution from glacial to interglacial sedimentary processes. Sediment. Geol. 1998, 117, 71-96. [CrossRef]

84. Van Rensbergen, P.; de Batist, M.; Beck, C.; Chapron, E. High-resolution seismic stratigraphy of glacial to interglacial fill of a deep glacigenic lake: Lake Le Bourget, Northwestern Alps, France. Sediment. Geol. 1999, 128, 99-129. [CrossRef]

85. Peach, P.A.; Perrie, L.A. Grain-Size Distribution within Glacial Varves. Geology 1975, 3, 43. [CrossRef]

86. Ridge, J.C.; Balco, G.; Bayless, R.L.; Beck, C.C.; Carter, L.B.; Dean, J.L.; Voytek, E.B.; Wei, J.H. The new North American Varve Chronology: A precise record of southeastern Laurentide Ice Sheet deglaciation and climate, 18.2-12.5 kyr BP and correlations with Greenland ice core records. Am. J. Sci. 2012, 312, 685-722. [CrossRef]

87. Piper, D.Z.; Isaacs, C.M. Geochemistry of Mi-Nor Elements in the Monterey Formation, California: Seawater Chemistry of Deposition; US Geological Survey Professional Paper 1556; USGS: Reston, VA, USA, 1995; Volume 1566, pp. 1-41.

88. Bergman, J.; Hammarlund, D.; Hannon, G.; Barnekow, L.; Wohlfarth, B. Deglacial vegetation succession and Holocene tree-limit dynamics in the Scandes Mountains, west-central Sweden: Stratigraphic data compared to megafossil evidence. Rev. Palaeobot. Palynol. 2005, 134, 129-151. [CrossRef]

89. Antonsson, $\mathrm{H}$. The extent of farm desertion in central Sweden during the late medieval agrarian crisis: Landscape as a source. J. Hist. Geogr. 2009, 35, 619-641. [CrossRef]

90. Karlsson, J.; Rydberg, J.; Segerström, U.; Nordström, E.-M.; Thöle, P.; Biester, H.; Bindler, R. Tracing a bog-iron bloomery furnace in an adjacent lake-sediment record in Ängersjö, central Sweden, using pollen and geochemical signals. Veg. Hist. Archaeobot. 2016, 25, 569-581. [CrossRef] 
91. Smol, J.P.; Wolfe, A.P.; Birks, H.J.B.; Douglas, M.S.V.; Jones, V.J.; Korhola, A.; Pienitz, R.; Ruhland, K.; Sorvari, S.; Antoniades, D.; et al. Climate-driven regime shifts in the biological communities of arctic lakes. Proc. Natl. Acad. Sci. USA 2005, 102, 4397-4402. [CrossRef] [PubMed]

92. Waters, C.N.; Zalasiewicz, J.; Summerhayes, C.; Barnosky, A.D.; Poirier, C.; Galuszka, A.; Cearreta, A.; Edgeworth, M.; Ellis, E.C.; Ellis, M.; et al. The Anthropocene is functionally and stratigraphically distinct from the Holocene. Science 2016, 351. [CrossRef] [PubMed]

93. Ek, A.S.; Renberg, I. Heavy metal pollution and lake acidity changes caused by one thousand years of copper mining at Falun, central Sweden. J. Paleolimnol. 2001, 26, 89-107. [CrossRef]

94. Rebesco, M.; Hernández-Molina, F.J.; Van Rooij, D.; Wåhlin, A. Contourites and associated sediments controlled by deep-water circulation processes: State-of-the-art and future considerations. Mar. Geol. 2014, 352, 111-154. [CrossRef]

95. Mulder, T.; Syvitski, J.P.M.; Migeon, S.; Faugères, J.-C.; Savoye, B. Marine hyperpycnal flows: Initiation, behavior and related deposits. A review. Mar. Pet. Geol. 2003, 20, 861-882. [CrossRef]

96. Chapron, E.; Desmet, M.; De Putter, T.; Loutre, M.F.; Beck, C.; Deconinck, J.F. Climatic variability in the northwestern Alps, France, as evidenced by 600 years of terrigenous sedimentation in Lake Le Bourget. Holocene 2002, 12, 177-185. [CrossRef]

97. Odegaard, C.; Rea, D.K.; Moore, T.C. Stratigraphy of the mid-Holocene black bands in Lakes Michigan and Huron: Evidence for possible basin-wide anoxia. J. Paleolimnol. 2003, 29, 221-234. [CrossRef]

98. Pitkänen, H.; Lehtoranta, J.; Räike, A. Internal Nutrient in External Load: Of Eastern Gulf Fluxes Counteract Decreases The Case of the Estuarial Eastern Gulf of Finland, Baltic Sea. Ambio 2001, 30, 195-201. [CrossRef] [PubMed]

99. Granina, L.; Müller, B.; Wehrli, B. Origin and dynamics of Fe and Mn sedimentary layers in Lake Baikal. Chem. Geol. 2004, 205, 55-72. [CrossRef]

100. Sander, M.; Bengtsson, L.; Holmquist, B.; Wohlfarth, B.; Cato, I. The relationship between annual varve thickness and maximum annual discharge (1909-1971). J. Hydrol. 2002, 263, 23-35. [CrossRef]

101. Haltia-Hovi, E.; Saarinen, T.; Kukkonen, M. A 2000-year record of solar forcing on varved lake sediment in eastern Finland. Quat. Sci. Rev. 2007, 26, 678-689. [CrossRef]

102. Ojala, A.E.K.; Alenius, T. 10,000 Years of interannual sedimentation recorded in the Lake Nautajärvi (Finland) clastic-organic varves. Palaeogeogr. Palaeoclimatol. Palaeoecol. 2005, 219, 285-302. [CrossRef]

103. Rothwell, R.G.; Hoogakker, B.; Thomson, J.; Croudace, I.W.; Frenz, M. Turbidite emplacement on the southern Balearic Abyssal Plain (western Mediterranean Sea) during Marine Isotope Stages 1-3: An application of ITRAX XRF scanning of sediment cores to lithostratigraphic analysis. In New Techniques in Sediment Core Analysis; Rothwell, R.G., Ed.; Geological Society: London, UK, 2006; Volume 267, pp. 79-98.

104. Huerta-Diaz, M.A.; Morse, J.W. Pyritization of trace metals in anoxic sediments. Geochim. Cosmochim. Acta 1992, 56, 2681-2702. [CrossRef]

105. Rothe, M.; Frederichs, T.; Eder, M.; Kleeberg, A.; Hupfer, M. Evidence for vivianite formation and its contribution to long-term phosphorus retention in a recent lake sediment: A novel analytical approach. Biogeosciences 2014, 11, 5169-5180. [CrossRef]

106. Manning, P.G.; Murphy, T.P.; Prepas, E.E. Intensive formation of vivianite in the bottom sediments of mesotrophic Narrow Lake, Alberta. Can. Mineral. 1991, 29, 77-85.

107. O'Connell, D.W.; Mark Jensen, M.; Jakobsen, R.; Thamdrup, B.; Joest Andersen, T.; Kovacs, A.; Bruun Hansen, H.C. Vivianite formation and its role in phosphorus retention in Lake Ørn, Denmark. Chem. Geol. 2015, 409, 42-53. [CrossRef]

108. Kullman, L.; Kjällgren, L. Holocene pine tree-line evolution in the Swedish Scandes: Recent tree-line rise and climate change in a long-term perspective. Boreas 2006, 35, 159-168. [CrossRef]

109. Kullman, L. Ecological tree line history and palaeoclimate-Review of megafossil evidence from the Swedish Scandes. Boreas 2013, 42, 555-567. [CrossRef]

110. Barnekow, L.; Bragée, P.; Hammarlund, D.; St. Amour, N. Boreal forest dynamics in north-eastern Sweden during the last 10,000 years based on pollen analysis. Veg. Hist. Archaeobot. 2008, 17, 687-700. [CrossRef]

111. SMHI (Swedish Meteorological and Hydrological Institute). Översvämningar i Sverige (Floods in Sweden); SMHI: Stockholm, Sweden, 2004.

112. Sander, M. Climatic Signals and Frequencies in the Swedish Time Scale, River Angermanälven, Central Sweden; Lund University: Lund, Sweden, 2003. 
113. Støren, E.N.; Paasche, Ø. Scandinavian floods: From past observations to future trends. Glob. Planet. Chang. 2014, 113, 34-43. [CrossRef]

114. Martin-Puertas, C.; Matthes, K.; Brauer, A.; Muscheler, R.; Hansen, F.; Petrick, C.; Aldahan, A.; Possnert, G.; van Geel, B. Regional atmospheric circulation shifts induced by a grand solar minimum. Nat. Geosci. 2012, 5, 397-401. [CrossRef]

115. Holzhauser, H.; Magny, M.; Zumbühl, H.J. Glacier and lake-level variations in west-central Europe over the last 3500 years. Holocene 2005, 15, 789-801. [CrossRef]

116. Kroonenberg, S.B.; Abdurakhmanov, G.M.; Badyukova, E.N.; van der Borg, K.; Kalashnikov, A.; Kasimov, N.S.; Rychagov, G.I.; Svitoch, A.A.; Vonhof, H.B.; Wesselingh, F.P. Solar-forced 2600 BP and Little Ice Age highstands of the Caspian Sea. Quat. Int. 2007, 173-174, 137-143. [CrossRef]

117. Mauquoy, D.; Yeloff, D.; Van Geel, B.; Charman, D.J.; Blundell, A. Two decadally resolved records from north-west European peat bogs show rapid climate changes associated with solar variability during the mid-late Holocene. J. Quat. Sci. 2008, 23, 745-763. [CrossRef]

118. Czymzik, M.; Brauer, A.; Dulski, P.; Plessen, B.; Naumann, R.; von Grafenstein, U.; Scheffler, R. Orbital and solar forcing of shifts in Mid- to Late Holocene flood intensity from varved sediments of pre-alpine Lake Ammersee (southern Germany). Quat. Sci. Rev. 2013, 61, 96-110. [CrossRef]

119. Van Geel, B.; Heijnis, H.; Charman, D.J.; Thompson, G.; Engels, S. Bog burst in the eastern Netherlands triggered by the $2.8 \mathrm{kyr}$ BP climate event. Holocene 2014, 24, 1465-1477. [CrossRef]

120. Mellström, A.; Van Der Putten, N.; Muscheler, R.; De Jong, R.; Björck, S. A shift towards wetter and windier conditions in southern Sweden around the prominent solar minimum 2750 cal a BP. J. Quat. Sci. 2015, 30, 235-244. [CrossRef]

121. De Jong, R.; Hammarlund, D.; Nesje, A. Late Holocene effective precipitation variations in the maritime regions of south-west Scandinavia. Quat. Sci. Rev. 2009, 28, 54-64. [CrossRef]

122. Faust, J.C.; Knies, J.; Milzer, G.; Giraudeau, J. Terrigenous input to a fjord in central Norway records the environmental response to the North Atlantic Oscillation over the past 50 years. Holocene 2014, 24, 1411-1418. [CrossRef]

123. Cherry, J.; Cullen, H.; Visbeck, M.; Small, A.; Uvo, C. Impacts of the North Atlantic oscillation on Scandinavian hydropower production and energy markets. Water Resour. Manag. 2005, 19, 673-691. [CrossRef]

124. Ineson, S.; Scaife, A.A.; Knight, J.R.; Manners, J.C.; Dunstone, N.J.; Gray, L.J.; Haigh, J.D. Solar forcing of winter climate variability in the Northern Hemisphere. Nat. Geosci. 2011, 4, 753-757. [CrossRef]

125. Olsen, J.; Anderson, N.J.; Knudsen, M.F. Variability of the North Atlantic Oscillation over the past 5200 years. Nat. Geosci. 2012, 5, 808-812. [CrossRef]

126. Bjune, A.E.; Bakke, J.; Nesje, A.; Birks, H.J.B. Holocene mean July temperature and winter precipitation in western Norway inferred from palynological and glaciological lake-sediment proxies. Holocene 2005, 15, 177-189. [CrossRef]

(C) 2018 by the authors. Licensee MDPI, Basel, Switzerland. This article is an open access article distributed under the terms and conditions of the Creative Commons Attribution (CC BY) license (http:/ / creativecommons.org/licenses/by/4.0/). 